In cooperation with the Bureau of Indian Affairs

\title{
Analysis of the Magnitude and Frequency of Peak Discharges for the Navajo Nation in Arizona, Utah, Colorado, and New Mexico
}

Scientific Investigations Report 2006-5306 
Blank Page 


\section{Analysis of the Magnitude and Frequency of Peak Discharges for the Navajo Nation in Arizona, Utah, Colorado, and New Mexico}

By Scott D. Waltemeyer

Prepared in cooperation with the Bureau of Indian Affairs

Scientific Investigations Report 2006-5306 


\title{
U.S. Department of the Interior DIRK KEMPTHORNE, Secretary
}

\author{
U.S. Geological Survey \\ Mark D. Myers, Director
}

\section{U.S. Geological Survey, Reston, Virginia: 2006}

For sale by U.S. Geological Survey, Information Services

Box 25286, Denver Federal Center

Denver, CO 80225

For more information about the USGS and its products:

Telephone: 1-888-ASK-USGS

World Wide Web: http://www.usgs.gov/

Any use of trade, product, or firm names in this publication is for descriptive purposes only and does not imply endorsement by the U.S. Government.

Although this report is in the public domain, permission must be secured from the individual copyright owners to reproduce any copyrighted materials contained within this report.

Suggested citation:

Waltemeyer, S.D., 2006, Analysis of the magnitude and frequency of peak discharges for the Navajo Nation in Arizona, Utah, Colorado, and New Mexico: U.S. Geological Survey Scientific Investigations Report 2006-5306, 42 p. 


\section{Contents}

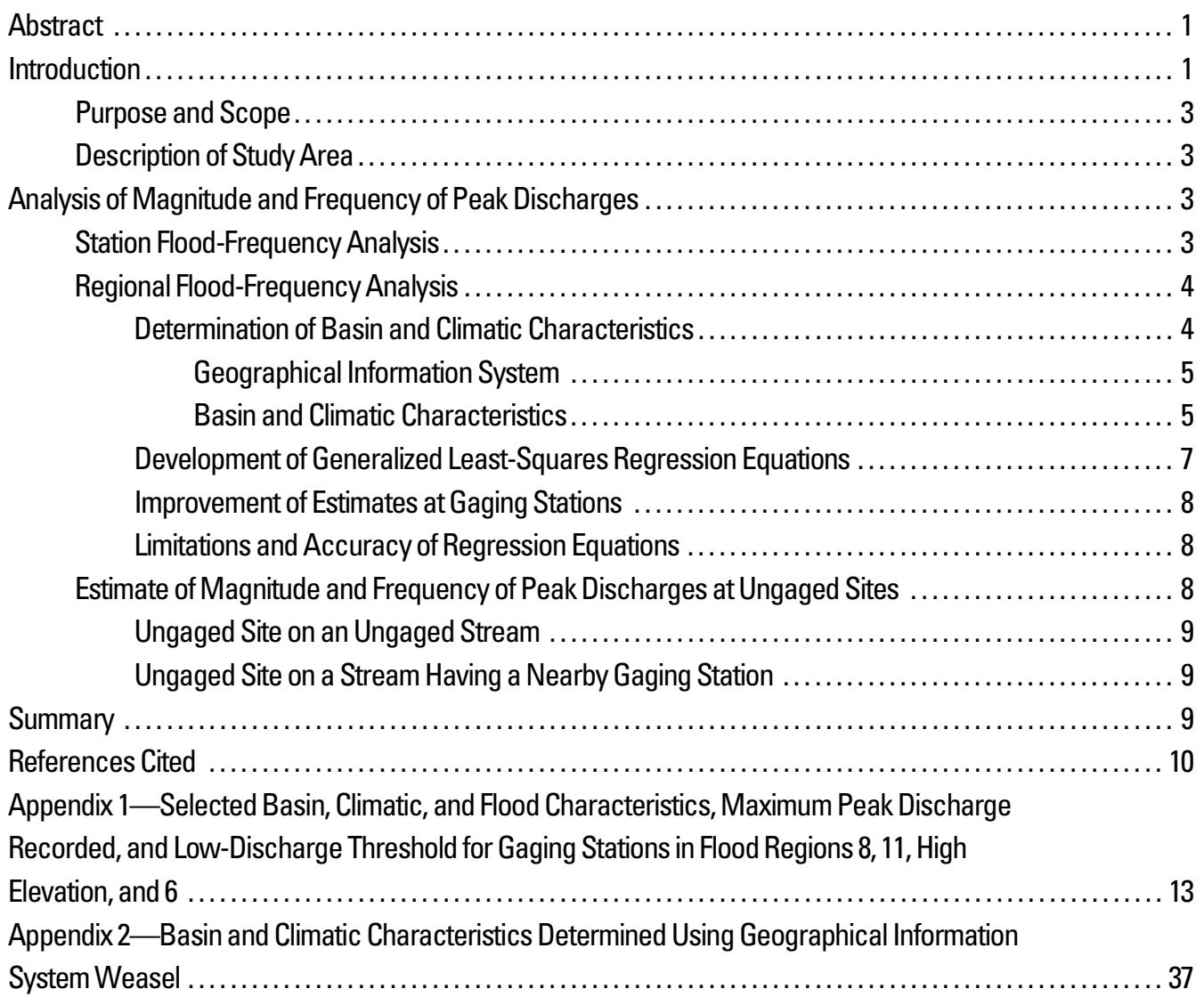

\section{Figure}

1. Map showing boundaries, flood regions, and locations of gaging stations in the Navajo Nation and surrounding region

\section{Tables}

1. Range of statistically significant basin characteristics selected for use in the regression

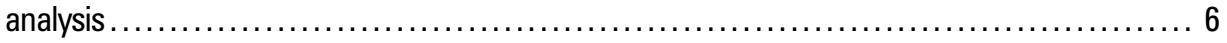

2. Regional flood-frequency equations using generalized least-squares regression $\ldots \ldots \ldots \ldots \ldots \ldots 7$ 


\section{Conversion Factors and Datums}

\begin{tabular}{lcl}
\hline Multiply & By & To obtain \\
\hline inch & 25.40 & millimeter \\
foot $(\mathrm{ft})$ & 0.3048 & meter $(\mathrm{m})$ \\
mile $(\mathrm{mi})$ & 1.609 & kilometer $(\mathrm{km})$ \\
square mile $\left(\mathrm{mi}^{2}\right)$ & 2.590 & square kilometer \\
cubic foot per second $\left(\mathrm{ft}^{3} / \mathrm{s}\right)$ & 0.02832 & cubic meter per second \\
\hline
\end{tabular}

Horizontal coordinate information is referenced to the North American Datum of 1983 (NAD 83).

Vertical coordinate information is referenced to the North American Vertical Datum of 1988 (NAVD 88).

Elevation, as used in this report, refers to distance above the vertical datum. 


\title{
Analysis of the Magnitude and Frequency of Peak Discharges for the Navajo Nation in Arizona, Utah, Colorado, and New Mexico
}

\author{
By Scott D. Waltemeyer
}

\section{Abstract}

Estimates of the magnitude and frequency of peak discharges are necessary for the reliable flood-hazard mapping in the Navajo Nation in Arizona, Utah, Colorado, and New Mexico. The Bureau of Indian Affairs, U.S. Army Corps of Engineers, and Navajo Nation requested that the U.S. Geological Survey update estimates of peak discharge magnitude for gaging stations in the region and update regional equations for estimation of peak discharge and frequency at ungaged sites.

Equations were developed for estimating the magnitude of peak discharges for recurrence intervals of 2, 5, 10, 25, 50, 100, and 500 years at ungaged sites using data collected through 1999 at 146 gaging stations, an additional 13 years of peakdischarge data since a 1997 investigation, which used gagingstation data through 1986. The equations for estimation of peak discharges at ungaged sites were developed for flood regions 8 , 11, high elevation, and 6 and are delineated on the basis of the hydrologic codes from the 1997 investigation.

Peak discharges for selected recurrence intervals were determined at gaging stations by fitting observed data to a log-Pearson Type III distribution with adjustments for a low-discharge threshold and a zero skew coefficient. A lowdischarge threshold was applied to frequency analysis of 82 of the 146 gaging stations. This application provides an improved fit of the log-Pearson Type III frequency distribution. Use of the low-discharge threshold generally eliminated the peak discharge having a recurrence interval of less than 1.4 years in the probability-density function.

Within each region, logarithms of the peak discharges for selected recurrence intervals were related to logarithms of basin and climatic characteristics using stepwise ordinary leastsquares regression techniques for exploratory data analysis. Generalized least-squares regression techniques, an improved regression procedure that accounts for time and spatial sampling errors, then was applied to the same data used in the ordinary least-squares regression analyses. The average standard error of prediction for a peak discharge have a recurrence inter- val of 100-years for region 8 was 53 percent (average) for the 100 -year flood. The average standard of prediction, which includes average sampling error and average standard error of regression, ranged from 45 to 83 percent for the 100 -year flood. Estimated standard error of prediction for a hybrid method for region 11 was large in the 1997 investigation. No distinction of floods produced from a high-elevation region was presented in the 1997 investigation. Overall, the equations based on generalized least-squares regression techniques are considered to be more reliable than those in the 1997 report because of the increased length of record and improved GIS method.

Techniques for transferring flood-frequency relations to ungaged sites on the same stream can be estimated at an ungaged site by a direct application of the regional regression equation or at an ungaged site on a stream that has a gaging station upstream or downstream by using the drainage-area ratio and the drainage-area exponent from the regional regression equation of the respective region.

\section{Introduction}

Estimates of the magnitude and frequency of peak discharges at unregulated streams at gaging stations or ungaged stream sites in the Navajo Nation in Arizona, Utah, Colorado, and New Mexico (fig. 1) are necessary for reliable flood-hazard mapping. The 100-year recurrence interval is mandated by the Federal Emergency Management Agency for mapping floodhazard areas for housing development. The magnitude of the peak discharge with a 100-year recurrence interval has an annual exceedance frequency of 1 percent and occurs, on average, at least once in a 100-year period. The United States Congress authorized the U.S. Army Corps of Engineers (USACE) to map flood-hazard areas for the Navajo Nation. The Bureau of Indian Affairs, USACE, and Navajo Nation requested that the U.S. Geological Survey (USGS) update estimates of peak discharge magnitude for gaging stations in the region and update regional equations for estimation of peak discharge and frequency at ungaged sites. 


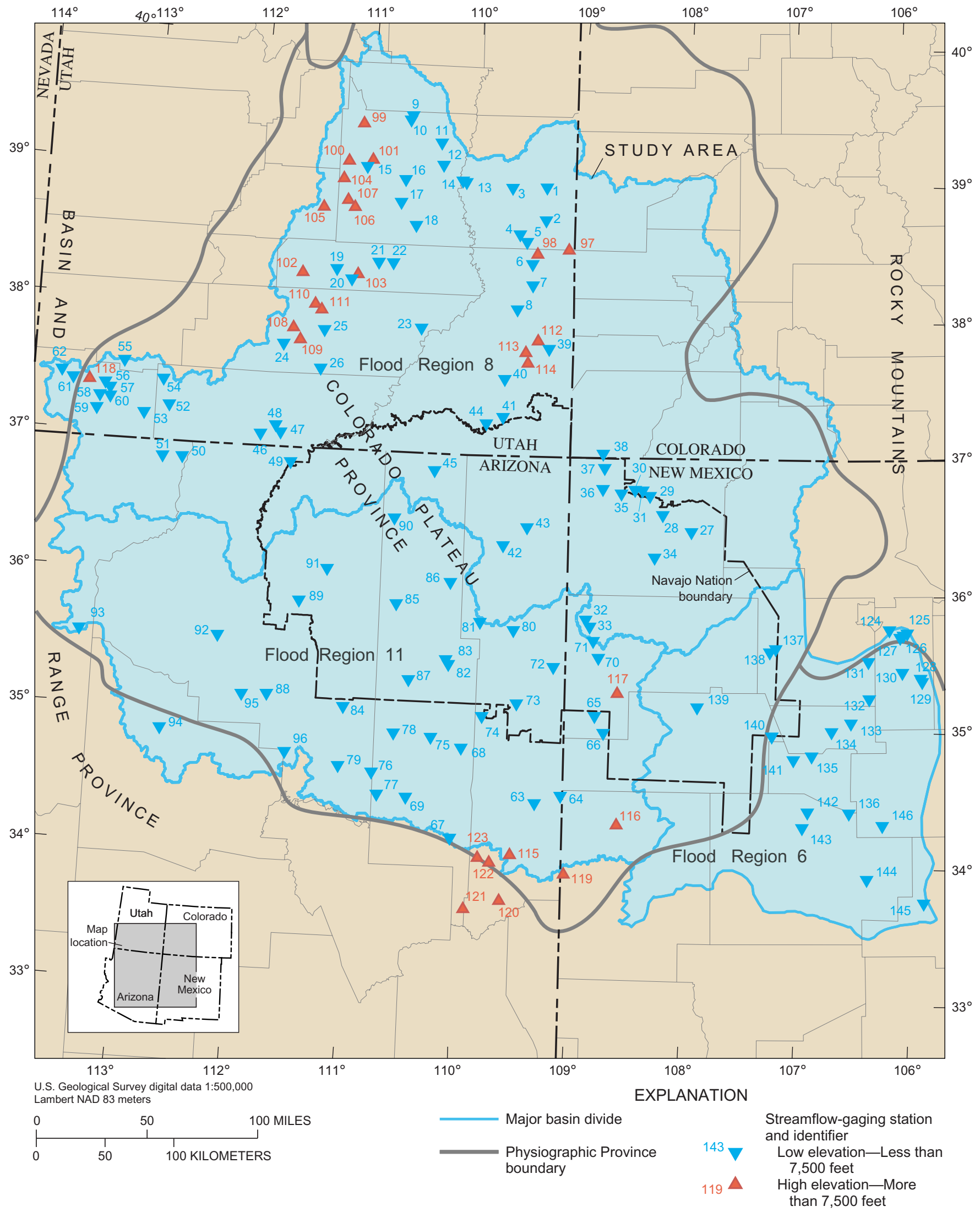

Figure 1. Boundaries, flood regions, and locations of gaging stations in the Navajo Nation and surrounding region. 
The most recent publication for estimating magnitude and frequency of floods for the Navajo Nation and surrounding region was completed in 1997 (Thomas and others, 1997). Thomas and others (1997) included analysis of flood data collected for about 1,300 gaging stations from beginning of record through 1986 and presented equations for estimation of peak discharges for various frequencies based on basin and climatic characteristics for 15 physiographic regions in the western United States. Thomas and others (1997) determined that the use of a zero for the generalized skew coefficient and a lowdischarge threshold improved the fit of the log-Pearson III distribution to recorded peak discharge data in the southwestern United States. In addition to the investigation by Thomas and others (1997), another statistical regression analysis approach—generalized least squares (Stedinger and Tasker, 1985), also has statistically improved estimation of regional flood-frequency relations and is used in this report.

\section{Purpose and Scope}

This report presents updated estimates of the magnitude and frequency of peak discharges at gaging stations based on 13 additional years (since 1986) of data collected since the Thomas and others (1997) investigation and improved equations for estimates of magnitude and frequency of peak discharges at ungaged sites. The report presents new and updated basin and climatic characteristics using an improved geographical information system (raster modeling) and the National Elevation Dataset. The magnitudes of peak discharges were determined for recurrence intervals of 2, 5, 10, 25, 50,100, and 500 years for 146 unregulated gaging stations. The frequency analyses are based on data for 146 gaging stations that generally have 10 or more years of record. The equations for estimation of peak discharges at ungaged sites were developed for four flood regions-regions 8, 11, high elevation, and 6. Also presented in this report is the average basin slope and a discussion of significant improvements in the prediction error of the regression models, which is attributed to the improved accuracy in the determination of drainage area and average basin elevation.

\section{Description of Study Area}

The physiography of the Navajo Nation and surrounding region is varied and complex and includes mountains, plains, plateaus, valleys, and deserts. The Rocky Mountains end in northern New Mexico, bounding the region on the east. The Colorado Plateau Province in the northern part of the study area consists of nearly horizontal layers of sedimentary rocks, generally ranges in elevation from about 5,000 to $11,000 \mathrm{ft}$, and has many canyons and escarpments. Landforms include plains, plateaus, pediments, and isolated mountains. The Basin and Range Province in the western and southern part of the study area has mostly isolated block mountains separated by aggraded desert plains. The southeast mountains commonly rise abruptly from the valley floors and have piedmont plains that extend downward to neighboring basin floors. Several flat desert areas are interspersed between the mountains, and some of these areas are lake deposits that have not been covered with water for hundreds of years. Many of the piedmont plains contain distributary-flow areas that consist of material deposited by mountainfront runoff (Thomas and others, 1997).

Storms that originate in the Pacific Ocean travel over the mountains and locally intensify in the plains area of the four corners region (Arizona, Utah, Colorado, and New Mexico). Regional thunderstorms develop over the mountains during early and late summer. The greatest monthly precipitation and localized areas of rainfall typically occur in July and August. Intense, convective midsummer storms that commonly are preceded by mild rainfall can produce severe flooding.

Floods in mountainous regions generally are produced by snowmelt and rarely by rainfall on snowpack. Floods in the plains, plateaus, valleys, and deserts almost always are produced by rainfall.

\section{Analysis of Magnitude and Frequency of Peak Discharges}

Peak-discharge data collected at crest-stage gages and continuously recording gaging stations were used to estimate the magnitude and frequency of peak discharges using a logPearson Type III probability distribution (Interagency Advisory Committee on Water Data, 1982). The peak-discharge characteristics at the gaging stations were related to basin and climatic characteristics using generalized least-squares (GLS) regression analyses.

\section{Station Flood-Frequency Analysis}

Peak-discharge data at gaging stations consist of a period of gaged record through 1999 of annual peak discharges, referred to as the systematic record, and stations with one or more historic, extreme discharges outside the systematic record (Interagency Advisory Committee on Water Data, 1982). Relating the magnitudes of annual peak discharges, generally referred to as flood-frequency data or characteristics, to their expected frequency of exceedance is termed a flood-frequency analysis. The frequency of peak discharges generally is expressed in terms of exceedance probability or recurrence intervals. Exceedance probability is the probability that a flood will exceed a given magnitude in any year. Recurrence interval, in years, is the reciprocal of the exceedance probability. For example, a flood with an exceedance probability of 0.01 has a recurrence interval of 100 years. The term "recurrence interval" is used in this report for simplicity.

Peak discharges for selected recurrence intervals were determined for each of 146 gaging stations using the logPearson Type III probability distribution as recommended by the Interagency Advisory Committee on Water Data (1982). Various adjustments for low outliers, zero-flow years, historic peak discharges, user-defined low-discharge threshold, and a 


\section{Magnitude and Frequency of Peak Discharges for the Navajo Nation in Arizona, Utah, Colorado, and New Mexico}

user-defined generalized coefficient of skewness were applied to station data where applicable.

Floods in the United States are derived mainly from four different mixed populations: rainfall, snowmelt runoff, rain on snowpack, from remnants of hurricanes or tropical storms. Some outliers existed in the annual peak-discharge series, which most likely was from a population other than the typical rainfall derived population; however an adequate number of annual peak-discharge data to define these rare populations was not recorded to date (1999) for any of the gaging stations in the study area. Annual peak discharges caused by annual snowmelt runoff from mountainous regions, annual peak discharges caused by annual rainfall runoff from convective thunderstorms are the most common, and annual peak discharges caused by annual rainfall runoff from infrequent remnants of hurricanes or tropical storms are the rare populations. Composite frequency analysis is required for some sites that have mixed populations. Crippen (1978) described techniques for making a composite analysis primarily from two populations of annual peak discharges, those caused by snowmelt runoff and rainfall runoff. The populations that cause floods were described in the 198889 National Water Summary (U.S. Geological Survey, 1991). Only a few gaging stations have recorded extreme peak discharges that plot as high outliers from the main distribution. Data on the separate sample populations for these rare storms are inadequate, thus a composite frequency analysis could not be performed.

The low-discharge threshold was used in investigations of flood frequency in the southwestern United States by Waltemeyer (1996) and Thomas and others (1997). The userdefined low-discharge threshold is based on the rationale that, in some instances, discharges less than some threshold value are not from the same population of peak discharges as the larger peak discharges. A probability-density-function plot of annual series data indicates that these low discharges have a different slope than the larger peak discharges. As a result, the overall fit of the probability distribution is affected, and peak discharges for large recurrence intervals tend to be underestimated when the low discharges are included. The low-discharge threshold was visually selected from the probability-density-function plots and applied to the frequency analysis of 82 of the 146 gaging stations (four flood regions in appendix 1). Use of the lowdischarge threshold generally eliminated the peak discharges having a recurrence interval less than 1.4 years.

The skew coefficient used in the log-Pearson Type III analysis is a weighted value determined by weighting the station skew with a generalized skew in inverse proportion to its mean-square errors (Interagency Advisory Committee on Water Data, 1982). In this report, a generalized skew is used based on research in prior investigations. The station skew used in an investigation in New Mexico (Waltemeyer, 1986) ranged from -0.22 to $0.29 \log$ units for the physiographic regions; previous investigations have reported the median for most of the regions as close to zero (Waltemeyer, 1986). A recent investigation of flood frequency for the southwestern United States (Thomas and others, 1997) also used zero for the generalized skew. Results from the investigation indicated that the meansquare error of generalized skew was 0.31 ; the same meansquare error was considered to be applicable for the investigation described in this report. Accordingly, the generalized skew for the four flood regions $(8,11$, high elevation, and 6$)$ was considered to be zero for this investigation.

The USGS computer program PEAKFQ (Kirby, 1981) was used to perform the flood-frequency analyses. Peakdischarge data and basin characteristics were determined from the NWISWeb (U.S. Geological Survey, 2001) and GIS (GIS Weasel) computerized systems (U.S. Geological Survey, 2000) and entered in the ANNIE data-management program (Lumb and others, 1990) for analysis. Selected basin, climatic, and flood characteristics for each station are listed in appendixes 1 and 2 .

\section{Regional Flood-Frequency Analysis}

Regionalization of flood-frequency characteristics with basin and climatic characteristics is mandated to estimate peak discharge at ungaged sites (New Mexico Department of Transportation, 1995). The magnitude of peak discharge is influenced by the basin and climatic characteristics of a physiographic region. In the western United States, Thomas and others (1997) identified two flood regions that have different flood characteristics (regions 8 and 11). These two flood regions, a region in New Mexico (region 6), and a high-elevation region (greater than 7,500 ft in elevation) were used for this report. Floods in regions 8,11 , and 6 are generally in response to rainfall runoff, whereas floods at elevations greater than 7,500 ft (highelevation region) are generally in response to snowmelt runoff (Jarrett and Costa, 1982). These regions generally correspond to the hydrologic unit code defined by the USGS (Seaber and others 1987). The regional equations developed for these four flood regions attempt to explain flood response with selected basin and climatic characteristics. Each region has unexplained variation, largely from basin and climatic characteristics that are not measured and used in the regional equations.

Ordinary least-squares (OLS) regression techniques (Minitab, Inc., 2003) were used to determine the most appropriate basin and climatic variables. Generalized least-squares (GLS) regression analysis (Stedinger and Tasker, 1985) was used to determine the values of the regression constant, regression coefficients, and the error terms of the regression equations.

\section{Determination of Basin and Climatic Characteristics}

Regional equations commonly are used for estimating the magnitude and frequency of peak discharges at locations that have no streamflow data. Equations have been developed from a regression analysis that relate peak discharges for recurrence intervals determined at gaging stations to basin and climatic characteristics. 


\section{Geographical Information System}

Basin and climatic characteristics were computed using an ARC/INFO geographical information system (GIS) (ESRI, 1999) and algorithms in the GIS Weasel developed by the USGS (U.S. Geological Survey, 2000). The GIS Weasel uses a graphical-user interface based on the ARC/INFO, arc macro language (AML) scripts, and $\mathrm{C}++$ programming language. The operation of the GIS Weasel does not require GIS expertise, but knowledge of ARC/INFO is helpful in changing the geographical projections from decimal degrees to other projections and in merging grids. The GIS Weasel online computer program (U.S. Geological Survey, 2000) was used to derive basin and climatic characteristics from raster data. The GIS Weasel uses a GRID subsystem of ARC/INFO to discretize coverages (vector data) into grids of cells with specific dimensions (for example, $85 \mathrm{ft}$ by $85 \mathrm{ft}$ ) and to assign a data value to each grid cell. The grid of data values represents some aspect of the discretized coverage, such as elevation or precipitation. The data values can be manipulated by applying mathematical operations to individual cells, to the whole grid, or by combining two or more grids. The GIS Weasel runs on a Unix or Windows NT platform and is available for downloading at http://wwwbrr.cr.usgs.gov/ weasel/, accessed July 10, 2000. Coverages of vector data were converted to raster data by discretizing coverages into a regularly spaced grid. The rasterization of the vector data or the use of raster data herein is referred to as "raster modeling." Grid cells were assigned data values representing geospatial characteristics.

\section{Basin and Climatic Characteristics}

The following basin and climatic characteristics were determined with raster modeling by using GIS Weasel (appendix 2): average basin mean annual precipitation (1961-90), average basin mean winter precipitation (1961-90), average basin maximum 24-hour and 6-hour precipitation for 100-year recurrence interval using NOAA Atlas's 2 (Miller and others, 1973) and Atlas 14 (Bonnin and others, 2004), average basin slope, drainage area, average basin elevation, and average basin aspect. Existing basin and climatic characteristics also were available from the USGS Water-Data Storage and Retrieval System (WATSTORE) computerized data system (Dempster, 1981; 1983). Existing data values for the basin and climatic characteristics were not used in the analysis because the only other significant characteristics in previous reports were average channel elevation and mean minimum January temperature. The average basin slope determined in this investigation was thought to be superior to average channel elevations and January temperature characteristic was considered to be an inherent characteristic in average basin elevation.

The National Elevation Dataset (NED) is a USGS raster product (U.S. Geological Survey, 1999) designed to provide national elevation data in a seamless form with a consistent datum, elevation unit, and cartographic projection. Seamless means that all 7.5-min quadrangles for each State can be compiled into a single coverage or layer. Data corrections were made in the NED assembly process to minimize artifacts, permit edge matching, and fill sliver areas of missing data. The NED has a resolution of 1 arc-second (approximately $30 \mathrm{~m}$ or $91 \mathrm{ft}$ ) for the conterminous United States. For example, the New Mexico 7.5-min, 30-m NED actual cell size is $28 \mathrm{~m}$ ( $85 \mathrm{ft}$ ). In the NED assembly process, the elevation values were converted to decimal meters as a consistent unit of measure, the North American Datum (NAD) of 1983 consistently was used as a horizontal datum, and all data were recast in a geographic projection of decimal degrees. The web page describing the NED is available at http://edcnts12.cr.usgs.gov/ned/, accessed June 7, 2006.

The GIS Weasel (U.S. Geological Survey, 2000) aids in the preparation of spatial information for input to merged and distributed parameter physical-process models. GIS Weasel provides tools to delineate, characterize, modify, and parameterize "model response units" (MRU's) within a geographical area; in this report, the area is the watershed or drainage area. An MRU in a watershed is typically used to represent an area that is characterized or attributed to estimate a uniform physical hydrologic process. Selected basin and climatic characteristics were computed for each watershed (average basin mean annual precipitation, average basin mean winter precipitation, average basin maximum 24-hour and 6-hour precipitation for 100-year recurrence interval using NOAA Atlas's 2 (Miller and others, 1973) and 14 (Bonnin and others, 2004), average basin slope, drainage area, average basin elevation, and average basin aspect) using a single MRU for each watershed. The 7.5-min digital elevation models (DEM's) of the NED were used for Arizona, Utah, Colorado, and New Mexico. The mean annual and winter precipitation grids were composed for the fourcorner States. A point coverage (latitude and longitude) was developed for the gaging-station locations listed in appendix 1.

Drainage area (DA), in square miles, typically is determined by planimetering the delineated area on the largest scale topographic maps available (generally the 7.5-min quadrangles, 1:24,000-scale). In this investigation, DA was determined by raster modeling using 7.5-min, 30-m DEM's. Average basin mean winter precipitation $(\mathrm{Pw})$ and average basin mean annual precipitation (Pa) (1961-90, in inches) were averaged for each basin by raster modeling using a 4-km (2.5-mi) grid developed by Daly and others (1998) for Arizona, Utah, Colorado, and New Mexico. Average basin slope (S), in percent, was averaged for each basin by raster modeling using the grid cells of the 7.5-min, 30-m DEM's. Average basin aspect (A), in degrees from north, was averaged for each basin by raster modeling using the grid cells of the 7.5-min, 30-m DEM's. Average basin elevation (E), in feet, was averaged for each basin by raster modeling using the grid cells of the 7.5-min, 30-m DEM's.

Estimates of mean monthly and mean annual precipitation for 1961-90 have been developed for 4-km (2.5-mi) grid cells by Daly and others (1998) for Arizona, Utah, Colorado, and New Mexico using the Parameter-Elevation Regressions on Independent Slopes Model (PRISM) presented by Daly and others (1994). PRISM estimates are based on all available point data, including the high-elevation precipitation data from the 


\section{Magnitude and Frequency of Peak Discharges for the Navajo Nation in Arizona, Utah, Colorado, and New Mexico}

Natural Resources Conservation Service data collection, and a DEM to account for the effects of topography through station weighting and simple linear regression of precipitation and elevation. The mean monthly precipitation raster datasets are available at http://www.ocs.orst.edu/prism/prism_new.html, accessed November 15, 1999. The raster precipitation data units are in millimeters multiplied by 100 , and the geographical coordinates of the grid cells are in decimal degrees.

The mean monthly precipitation (1961-90) raster data were available only by month. By using the 12 monthly values of 30-year mean precipitation for each grid cell, the GRID subsystem of ARC/INFO was used to compute mean values for the annual 12-month period and for the 7-month winter period (October-April). GIS Weasel was used to compute an average, aerially weighted value for each basin from the values for the 4-km (2.5-mi) grid cells within each basin. Finally, total values of precipitation for each period were computed and converted from millimeters to inches by multiplying by the number of months in the period ( 7 for the winter and 12 for the annual) and dividing by 2,540 .

Drainage area determined using GIS Weasel for the 62 gaging stations in region 8 ranged from 0.06 to $4,350 \mathrm{mi}^{2}$; average basin slope ranged from 0.0231 to 0.4447 percent; and, average basin elevation ranged from 4,320 to 7,750 ft (table 1; appendix 1). Drainage area determined using GIS Weasel for the 34 gaging stations in region 11 ranged from 0.11 to $2,150 \mathrm{mi}^{2}$; average basin slope ranged from 0.0177 to 0.1545 percent (table 1; appendix 1); and, average basin elevation ranged from 5,010 to 7,440 ft (this variable was not significant in regression analysis; not listed in table 1 or appendix 1 ).

Table 1. Range of statistically significant basin characteristics selected for use in the regression analysis.

[--, indicates that characteristic is not statistically significant]

\begin{tabular}{lllc}
\hline Region & $\begin{array}{c}\text { Drainage } \\
\text { area } \\
\text { (square } \\
\text { miles) }\end{array}$ & $\begin{array}{c}\text { Average } \\
\text { basin } \\
\text { slope } \\
\text { (percent) }\end{array}$ & $\begin{array}{c}\text { Average } \\
\text { basin } \\
\text { elevation } \\
\text { (feet) }\end{array}$ \\
\hline Region 8 & 0.06 to & 0.0231 to & $\begin{array}{l}4,320 \text { to } \\
17,750\end{array}$ \\
& 4,350 & 0.4447 & \\
Region 11 & & & -- \\
& 0.11 to & 0.0177 to & - \\
Region high elevation & 2,150 & 0.1545 & - \\
(elevations greater than & 1.7 to & & -- \\
7,500 feet) & 1,200 & & - \\
Region 6 & & & - \\
\hline
\end{tabular}

\footnotetext{
${ }^{1}$ Two gaging stations used at average basin elevation above 7,500 feet.
}

Drainage area for the 27 gaging stations in region high elevation (elevations greater than 7,500 ft) ranged from 1.7 to $1,200 \mathrm{mi}^{2}$ (table 1; appendix 1); average basin slope ranged from 0.0851 to 0.4130 percent (this variable was not significant in regression analysis; not listed in table 1 or appendix 1); and, average basin elevation ranged from 7,680 to $10,960 \mathrm{ft}$ (this variable was not significant in regression analysis; not listed in table 1 or appendix 1). Drainage area for the 23 gaging stations in region 6 ranged from 0.18 to $7,220 \mathrm{mi}^{2}$ (table 1 ; appendix 1 ); average basin slope ranged from 0.0345 to 0.2096 percent (this variable was not significant in regression analysis; not listed in table 1 or appendix 1); and, average basin elevation ranged from 5,360 to $7,260 \mathrm{ft}$ (this variable was not significant in regression analysis; not listed in table 1 or appendix 1). Note that five gaging stations were outside the boundary of region 8 and 11, but nearby, because of the lack of data greater than 7,500 ft.

A stepwise OLS multiple-regression procedure (Minitab, Inc., 2003) was used to determine which independent variables were significant in the equations for peak discharge. In the stepwise procedure, variables were added one at a time until all that were significant at the 5-percent level were included. Because the logarithms of peak discharge commonly are determined to be linearly related to logarithms of basin and climatic variables, all variables were transformed to base 10 logarithms for the regression analysis. The general form of the mathematical model is:

$$
\begin{aligned}
\log \mathrm{Q}_{t} & =\log \mathrm{k}+\mathrm{a} \log \mathrm{x}_{1}+\mathrm{b} \log \mathrm{x}_{2}+\ldots+\mathrm{n} \log \mathrm{x}_{n} \\
\text { or } \mathrm{Q}_{t} & =\mathrm{K} \mathrm{x}_{1}{ }^{\mathrm{a}} \mathrm{x}_{2}{ }^{\mathrm{b}} \ldots \mathrm{x}_{n}{ }^{\mathrm{n}}
\end{aligned}
$$

where

$$
\begin{aligned}
\mathrm{Q}_{t}= & \text { peak discharge (instantaneous peak discharge), } \\
& \quad \text { in cubic feet per second }, \text { for recurrence } \\
& \quad \text { interval } \mathrm{t} ; \\
\mathrm{k}= & \text { regression constant; } \\
\mathrm{a}, \mathrm{b}, \ldots \mathrm{n}= & \text { regression coefficients; } \\
\mathrm{x}_{1}, \mathrm{x}_{2}, \ldots \mathrm{x}_{n}= & \text { basin and climatic variables; and } \\
\mathrm{K} & =\text { the anti-log of the regression constant. }
\end{aligned}
$$

One or more of the following basin and climatic characteristics was determined to be statistically significant for inclusion as independent variables in the regression equations:

A drainage area, in square miles;

$\mathrm{S}$ average basin slope upstream from the gaging station, in percent; and

E average basin elevation, in feet above NAVD 88.

Additional variables listed in appendix 2 also were determined using GIS, which include mean annual precipitation (1961-90), mean annual winter precipitation (1961-90), maximum 24-hour and 6-hour precipitation for 100-year recurrence intervals for NOAA Atlas 2 (Miller and others, 1973) and NOAA Atlas 14 (Bonnin and others, 2004), and average basin aspect. The maximum precipitation frequency from NOAA Atlas 2 was statistically significant in some flood regions in previous reports (Waltemeyer, 1986; 1996). Maximum precipitation characteristics from NOAA Atlas 2 and 14 were not statistically significant ( $\mathrm{p}$-value less than 5 percent). 


\section{Development of Generalized Least-Squares Regression Equations}

After the appropriate independent variables had been determined using the OLS regression, GLS regression was used to determine the best values of the regression coefficients.

Regression coefficients determined from a GLS regression procedure (Stedinger and Tasker, 1985; Tasker and others, 1986) are considered to be better than those determined from OLS regression because GLS regression considers the time-sampling error of the dependent variable, whereas OLS regression does not. GLS regression also considers cross correlation among concurrent peak discharges at gaging stations, whereas OLS regression does not. The basic regression model using GLS is shown as equation 1 . The equations determined using GLS regression analysis are listed in table 2 . Included are equations for estimating peak-discharge magnitudes that have recurrence intervals of 2, 5, 10, 25, 50, 100, and 500 years for each of the four regions in the Navajo Nation and surrounding region.

Table 2. Regional flood-frequency equations using generalized least-squares regression.

[Q, peak discharge, in cubic feet per second for indicated recurrence interval in years; A, drainage area, in square miles; S, average basin slope, in percent; E, average basin elevation, in feet; flood regions are listed in appendix 1]

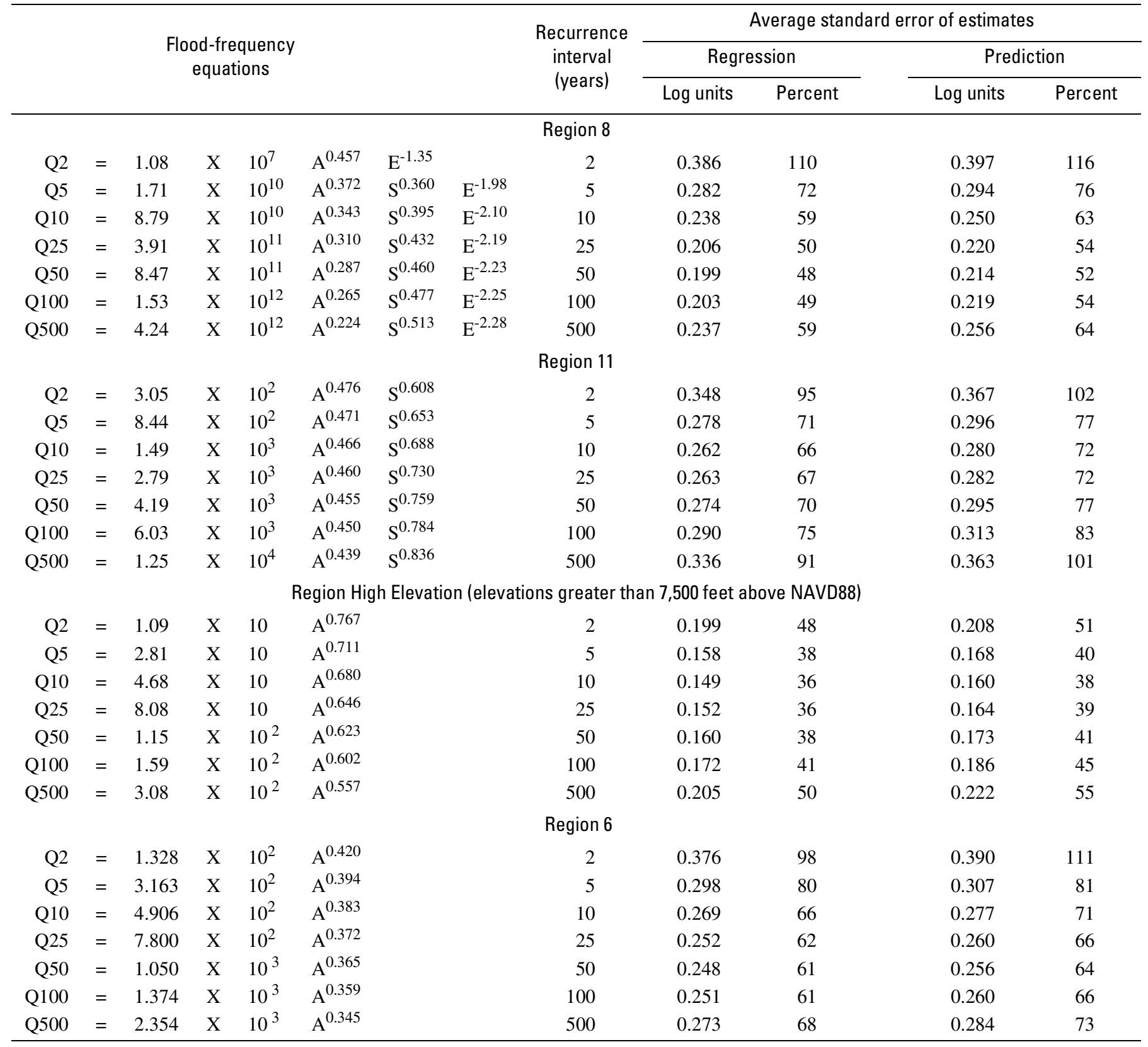




\section{Magnitude and Frequency of Peak Discharges for the Navajo Nation in Arizona, Utah, Colorado, and New Mexico}

\section{Improvement of Estimates at Gaging Stations}

Flood-frequency estimates for gaging stations having short-term records can be improved by weighting the station data with estimates from the regional regression equation (Interagency Advisory Committee on Water Data, 1982). The GLSNET (Regional Hydrologic Regression and Network Analysis using Generalized Least Squares) (Stedinger and Tasker, 1985) computer program computes the weighted estimate by using the observed station peak discharge, the regression-equation-predicted peak discharge, the equivalent years of record, and the actual record length. The observed (top line of data), predicted (middle line of data), and weighted (bottom line of data) flood-frequency data are listed in appendix 1 for each gaging station. Weighted estimates, considered to be the best estimates at gaging stations, were determined by:

$$
\mathrm{Q}_{w}=\left(\mathrm{n}_{i} \mathrm{y}_{i}+\mathrm{en}_{i} \mathrm{x}_{i} \mathrm{~b}\right) /\left(\mathrm{n}_{i}+\mathrm{en}_{i}\right)
$$

where

$$
\begin{aligned}
& \mathrm{Q}_{w}= \text { weighted flood-frequency data at the gaging station, in } \\
& \text { cubic feet per second; }
\end{aligned}
$$

The weighted estimate determined by equation 2 is a function of actual record length and equivalent years from the regression analysis. If actual record length is longer than equivalent years, more weight is given to the observed station data. Conversely, if actual record length is shorter than equivalent years, more weight is given to the regression estimate.

\section{Limitations and Accuracy of Regression Equations}

The intended use of regression equations is to provide reliable estimates of peak discharges for selected recurrence intervals at unregulated, ungaged stream sites in the Navajo Nation and surrounding areas. Estimates commonly are required for ungaged sites on ungaged streams and, often, for ungaged sites on streams that have gaging stations located near the ungaged sites. Estimates at ungaged sites in a basin located in two regions are less common and somewhat more difficult than for basins in one region. In parts of some regions, regression equations may not be reliable for areas with sparse data or for ungaged sites that have basin and climatic variables beyond the range of those listed in table 1 . The application of regional equations is not intended to preclude the use of sound hydrologic judgment or any other hydrologic or engineering method that may provide a more reliable estimate. Unit-hydrograph techniques that use gaged precipitation in a basin lacking gagingstation data may yield more reliable estimates of peak discharge than regional equations (Waltemeyer, 2002).
Accuracy of the GLS regression equations generally is measured by the average standard error of prediction and the equivalent years of record. The average standard error of prediction is the sum of the average regression or model error and the average sampling error. The average standard error of regression presented in table 2 for a 100 -year recurrence interval peak discharge ranged from 41 to 75 percent for the regions. The average standard error of prediction presented in table 2 for a 100 -year recurrence interval peak discharge ranged from 45 to 83 percent for the regions. Significant improvements over errors previously reported (Thomas and others, 1997) for regions 11, high elevation, and 6 are attributed to improved GIS determination of drainage area, average basin elevation, and the determination of average basin slope for the first time. Region 8 in the 1997 investigation presented a regression analysis using drainage area and mean basin elevation with a standard error of prediction of 53 percent (average) for the 100-year flood. Region 11 presented a hybrid method indicating a large estimated standard error of prediction. No distinction of floods produced from a high-elevation region was presented. Overall, the equations based on GLS regression are considered to be more reliable than those in the previous report because of the increased length of record and improved GIS method. The average standard error of prediction was calculated in log units and converted to percent by using methods described by Hardison (1971).

Equivalent years of record are an alternative measure of the accuracy of regression equations that are particularly useful for comparison to gaging-station data. Equivalent years of record are the number of years of actual peak-discharge record that would be required to achieve the same accuracy in the estimate of the t-year peak discharge as that obtained from the regional equation. Equivalent years of record are computed by the GLSNET computer program using the method described by Hardison (1971).

\section{Estimate of Magnitude and Frequency of Peak Discharges at Ungaged Sites}

Peak discharges that have various recurrence intervals can be estimated for ungaged sites on unregulated, ungaged streams from the regional equations listed in table 2. Gaging-station data can be extrapolated to estimate peak discharge at an ungaged site on a stream that has a nearby gaging station. Additionally, flood-frequency data are available for gaging stations on the main stems of some streams not used in this report for the development of regional regression relations. Data at these gaging stations can be used to make estimates at ungaged sites on the same stream. The independent variables that pertain to the equation for each region need to be measured as previously described for the development of the equations. These methods are described in more detail in the national handbook of recommended methods for water-data acquisition (U.S. Geological Survey, 1977) and in the section "Determination of Basin and 
Climatic Characteristics" in this report. The following sections present examples of the above procedures.

\section{Ungaged Site on an Ungaged Stream}

An estimate of peak discharge with a recurrence interval of 100 years is required for an ungaged site in region 8 that has a drainage area of $523 \mathrm{mi}^{2}$, average basin slope of 0.2422 , in percent, and a mean basin elevation of $6,940 \mathrm{ft}$. Using the equation in table 2 , the peak discharge for a 100-year recurrence interval is:

$$
\begin{aligned}
\mathrm{Q}_{100} & =1.53 \times 10^{12} \mathrm{~A}^{0.265} \mathrm{~S}^{0.477} \mathrm{E}^{-2.25} \\
& =\left(1.53 \times 10^{12}\right)(523)^{0.265}(0.2422)^{0.477}(6,940)^{-2.25} \\
& =8,510 \text { cubic feet per second }
\end{aligned}
$$

\section{Ungaged Site on a Stream Having a Nearby Gaging Station}

Flood-frequency estimates can be made for ungaged sites upstream or downstream from gaging stations by using a method developed by Thomas and others (1997). This method transfers flood-frequency data at the gaging station to the ungaged site by using the following drainage-area ratio adjustment equation:

$$
\mathrm{Q}_{T(u)}=\mathrm{Q}_{T(g)}\left(\mathrm{A}_{u} / \mathrm{A}_{g}\right)^{\mathrm{X}},
$$

where

$$
\begin{aligned}
& \mathrm{Q}_{T(u)}=\text { weighted flood-frequency estimate at the ungaged } \\
& \text { site, in cubic feet per second; } \\
& \mathrm{Q}_{T(g)}=\text { flood-frequency estimate at the gaging station, in } \\
& \text { cubic feet per second; } \\
& \mathrm{A}_{u}=\text { drainage area at the ungaged site, in square miles; } \\
& \mathrm{A}_{g}=\text { drainage area at the gaging station, in square miles; } \\
& \text { and } \\
& \mathrm{x}=\text { exponent of the drainage area of the applicable } \\
& \text { regional regression equation listed in table } 2 \text {. }
\end{aligned}
$$

According to Saur (1974) the equation is applicable when the drainage-area ratio is between 0.5 and 1.5. For example, to estimate a 50-year peak discharge at an ungaged site in region 8 upstream from gaging station Cisco Wash near Cisco, Utah

(09163700), the station value listed in appendix 1 is $4,820 \mathrm{ft}^{3} / \mathrm{s}$. Note that the weighted value of $5,770 \mathrm{ft}^{3} / \mathrm{s}$ was not used because the technique makes a regional adjustment using the exponent from the regional equation. The weighted value is considered the best flood-frequency value, and this technique would make a double weight based on the regional flood information. The drainage area at the gaging station is $90.7 \mathrm{mi}^{2}$ (appendix 1). The exponent of the drainage area of the regression equation for a 50 -year recurrence interval for region 8 is 0.287 (table 2). The drainage area at the ungaged site is $75.5 \mathrm{mi}^{2}$, and using equation 4 the peak discharge at the ungaged site is:

$$
\begin{aligned}
\mathrm{Q}_{50 u} & =\mathrm{Q}_{50 g}\left(\mathrm{~A}_{u} / \mathrm{A}_{g}\right)^{\mathrm{x}} \\
& =(4,820)(75.5 / 90.7)^{0.287} \\
& =4,580 \text { cubic feet per second. }
\end{aligned}
$$

\section{Summary}

Estimates of the magnitude and frequency of peak discharge are necessary for reliable flood-hazard mapping in the Navajo Nation in Arizona, Utah, Colorado, and New Mexico. The Bureau of Indian Affairs, U.S. Army Corps of Engineers, and Navajo Nation requested that the U.S. Geological Survey update estimates of peak discharge magnitude for gaging stations in the region and update regional equations for estimation of peak discharge and frequency at ungaged sites.

Equations were developed for estimating the magnitude of peak discharges for recurrence intervals of 2, 5, 10, 25, 50, 100, and 500 years at ungaged sites using data collected through 1999 at 146 gaging stations, an additional 13 years of peakdischarge data since the 1997 investigation (gaging-station data through 1986). Peak discharges for selected recurrence intervals were determined at gaging stations by fitting observed data to a log-Pearson Type III probability distribution with adjustments for a low-discharge threshold and a zero skew coefficient. A low-discharge threshold was applied to frequency analysis of 82 gaging stations. This application provides an improved fit of the log-Pearson Type III frequency distribution. Use of the low-discharge threshold generally eliminated the peak discharges having a recurrence interval of less than 1.4 years in the probability-density function.

The National Elevation Dataset (30-meter resolution) was used with the U.S. Geological Survey computer program USGS GIS Weasel for determining basin and climatic characteristics. Statistically significant characteristics are drainage area, average basin slope, and average basin elevation. Other characteristics not statistically significant but determined using GIS include average basin mean annual precipitation (1961-90), average basin mean annual winter precipitation (1961-90), average basin maximum 24-hour and 6-hour precipitation for 100-year recurrence intervals for NOAA Atlas 2 and NOAA Atlas 14, and average basin aspect.

The equations reflect flood response for four distinct flood regions with a distinction of flood response from high elevation in or near four regions. The flood regions were delineated on the basis of the hydrologic unit codes from the 1997 investigation and are: (1) region $8,(2)$ region $11,(3)$ region high elevation, and (4) region 6. Within each region, logarithms of the peak discharges for selected recurrence intervals were related to logarithms of basin and climatic characteristics using stepwise ordinary least-squares regression techniques for exploratory data analysis. Generalized least-squares regression techniques, an improved regression procedure that accounts for time and spatial sampling errors, then was applied to the same data used in the ordinary least-squares regression analyses. The average standard error of prediction for a peak discharge having a recurrence interval of 100 years for region 8 was 53 percent (average) from the 1997 investigation. Estimated standard error of prediction for a hybrid method for region 11 was large in the 1997 investigation. Also, no distinction was made for floods produced from higher elevations. The average standard error of 
prediction, which includes average sampling error and average standard error of regression, ranged from 45 to 83 percent for the 100-year flood in this investigation. Overall, the equations based on generalized least squares regression techniques are considered to be more reliable than those in the 1997 investigation because of the increased length of record and improved GIS method.

Techniques for transferring flood-frequency relations to ungaged sites on the same stream can be estimated at an ungaged site on a stream that has a gaging station upstream or downstream by using the drainage-area ratio and the drainagearea exponent from the regional regression equation of the respective region.

\section{References Cited}

Bonnin, G.M., Todd, D., Lin, B., Parzybok, T., Yekta, M., and Riley, D., 2004, Precipitation-frequency atlas of the western United States, volume 1-Semiarid Southwest (Arizona, Southeast California, Nevada, New Mexico, and Utah): National Oceanic and Atmospheric Administration NOAA Atlas 14, $246 \mathrm{p}$.

Crippen, J.R., 1978, Composite log-Pearson Type III frequency-magnitude curve of annual floods: U.S. Geological Survey Open-File Report 78-352, 5 p.

Daly, C., Neilson, R.P., and Phillips, D.L., 1994, A statisticaltopographic model for mapping climatological precipitation over mountainous terrain: Journal of Applied Meteorology. v. 33, p. $140-158$.

Daly, C., 1998, Arizona average monthly or annual precipitation, 1961-90: Water and climate Center of the Natural Resources Conservation Service, Portland Oreg., accessed August 16, 2000, at URL http://www.ocs.orst.edu/pub/maps/ Precipitation/Total/States/AZ.

Daly, D., 1998, Colorado average monthly or annual precipitation, 1961-90: Water and climate Center of the Natural Resources Conservation Service, Portland Oreg., accessed August 16, 2000, at URL http://www.ocs.orst.edu/pub/maps/ Precipitation/Total/States/CO.

Daly, D., 1998, New Mexico average monthly or annual precipitation, 1961-90: Water and climate Center of the Natural Resources Conservation Service, Portland Oreg., accessed August 16, 2000, at URL http://www.ocs.orst.edu/pub/maps/ Precipitation/Total/States/NM.

Daly, D., 1998, Utah average monthly or annual precipitation, 1961-90: Water and climate Center of the Natural Resources Conservation Service, Portland Oreg., accessed August 16, 2000, at URL http://www.ocs.orst.edu/pub/maps/ Precipitation/Total/States/UT.

Dempster, G.R., 1981, Peak flow file, chapter I, section B, WATSTORE user's guide: U.S. Geological Survey OpenFile Report 79-1336-I, v. 4, p. B-1 to B-58.

Dempster, G.R., 1983, Streamflow basin characteristics, chapter II, section A, WATSTORE user's guide: U.S. Geological Survey Open-File Report 79-1336-I, v. 4, p. A-24 to A-34.
ESRI, 1999, ARC/INFO version 8.0.1: Redlands, Calif., Environmental Systems Research Institute, variously paged. Hardison, C.H., 1971, Prediction error of regression estimates of streamflow characteristics at ungaged sites, in Geological Survey Research 1971: U.S. Geological Survey Professional Paper 750-C, p. C228-C236.

Interagency Advisory Committee on Water Data, 1982, Guidelines for determining peak discharge frequency: Bulletin 17B of the Hydrology Subcommittee, Office of Water Data Coordination, U.S. Geological Survey, Reston, Va., 28 p. and appendices.

Jarrett, R.D., and Costa, J.E., 1982, Multidisciplinary approach to the flood hydrology of foothill streams in Colorado, in Proceedings, International Symposium of Hydrometerology: Denver, Colorado, American Water Resources Association, June 1982, p. 565-569.

Kirby, W.H., 1981, Peak flow file, chapter I, section C, WATSTORE user's guide: U.S. Geological Survey OpenFile Report 79-1336-I, v. 4, p. C-1 to C-57.

Lumb, A.M., Kittle, J.L., Jr., and Flynn, K.M., 1990, User's manual for ANNIE, a computer program for interactive hydrologic analyses and data management: U.S. Geological Survey Water-Resources Investigations Report 89-4080, $236 \mathrm{p}$.

Miller, J.F., Frederick, R.H., and Tracey, R.J., 1973, Precipitation-frequency atlas of the western United States, volume IV-New Mexico: National Oceanic and Atmospheric Administration NOAA Atlas 2, 43 p.

Minitab, Inc., 2003, Meet Minitab-release 14 for Windows, 2003: State College, Pa., p. 1-1 to 11-22.

New Mexico Department of Transportation, 1995, Drainage Manual Volume 1, Hydrology: Preliminary Design Bureau/Drainage Section, NMDOT, Santa Fe, NM, 92 p. and appendices.

Saur, V.B., 1974, Flood characteristics of Oklahoma Streams: U.S. Geological Survey Water-Resources Investigations Report 52-73, $301 \mathrm{p}$.

Seaber, P.R., Kapinos, F.P., and Knapp., G.L., 1987, Hydrologic Unit Maps: U.S. Geological Survey Water-Supply Paper 2294, 63 p.

Stedinger, J.R., and Tasker, G.D., 1985, Regional hydrologic analysis-Ordinary, weighted, and generalized least squares compared: Water Resources Research, v. 21, no. 9, p. 1,421-1,432.

Tasker, G.D., Eychaner, J.H., and Stedinger, J.R., 1986, Application of generalized least-squares in regional hydrologic regression analysis: U.S. Geological Survey Water-Supply Paper 2310, p. 107-115.

Thomas, B.E., Hjalmarson, H.W., and Waltemeyer, S.D., 1997, Methods for estimating magnitude and frequency of floods in the southwestern United States: U.S. Geological Survey Water Supply Paper 2433, 195 p.

U.S. Geological Survey, 1977, National handbook of recommended methods for water-data acquisition: Chap. VII, Office of Water Data Coordination (rev. June 1978), p. 9-15. 
U.S. Geological Survey, 1991, National water summary 1988-89-Hydrologic events and floods and droughts: U.S. Geological Survey Water-Supply Paper 2375, 591 p.

U.S. Geological Survey, 1999, National elevation dataset (NED) online data: U.S. Geological Survey, EROS Data Center, edition 1, accessed July 10, 2000, at URL http://edents12.cr.usgs.gov/ned.

U.S. Geological Survey, 2000, The GIS Weasel online data and program: U.S. Geological Survey, Branch of Regional Research, version 3.40, accessed July 10, 2000, at URL http://www.brr.cr.usgs/gov/weasel.

U.S. Geological Survey, 2001, NWISWeb Data for the Nation—online data: U.S. Geological Survey, Reston, VA, accessed July 10, 2003, at URL http://waterdata.usgs.gov/.
Waltemeyer, S.D., 1986, Techniques for estimating flood-flow frequency for unregulated streams in New Mexico: U.S. Geological Survey Water-Resources Investigations Report 86-4104, 56

Waltemeyer, S.D., 1996, Analysis of the magnitude and frequency of peak discharge and maximum observed peak discharge in New Mexico: U.S.Geological Survey WaterResources Investigations Report 96-4112, 79.

Waltemeyer, S.D., 2002, Analysis of the magnitude and frequency of the 4-day annual low flow and regression equations for estimating the 4-day, 3-year low-flow frequency at ungaged sites on unregulated streams in New Mexico: U.S. Geological Survey Water-Resources Investigations Report 01-4271, 22 p. 
Blank Page 


\section{Appendix 1-Selected Basin, Climatic, and Flood Characteristics, Maximum Peak Discharge Recorded, and Low-Discharge Threshold for Gaging Stations in Flood Regions 8, 11, High Elevation, and 6}




\section{Magnitude and Frequency of Peak Discharges for the Navajo Nation in Arizona, Utah, Colorado, and New Mexico}

Appendix 1. Selected basin, climatic, and flood characteristics, maximum peak discharge recorded and low-discharge threshold for

[Peak discharge values in cubic feet per second: first line, station value used in regression analysis; second line, predicted value using regression equation; third previously published from manual delineation (Dempster, 1983). Blank basin slope or elevation indicates variable not statistically significant]

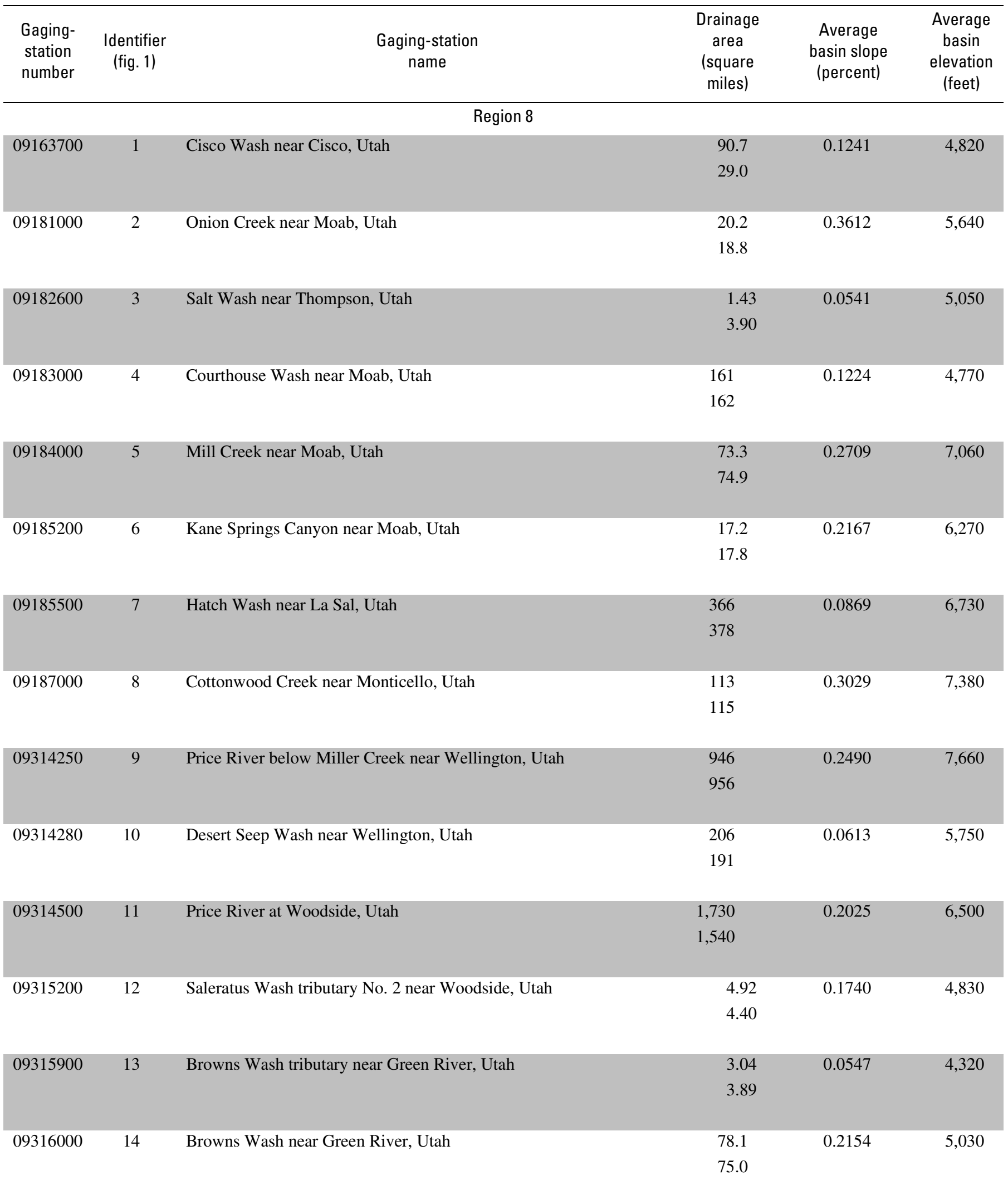


gaging stations in flood regions 8,11 , high elevation, and 6 -Continued.

line, weighted value with station and predicted value. --, no data; drainage area: first line determined from geographic information system analysis; second line,

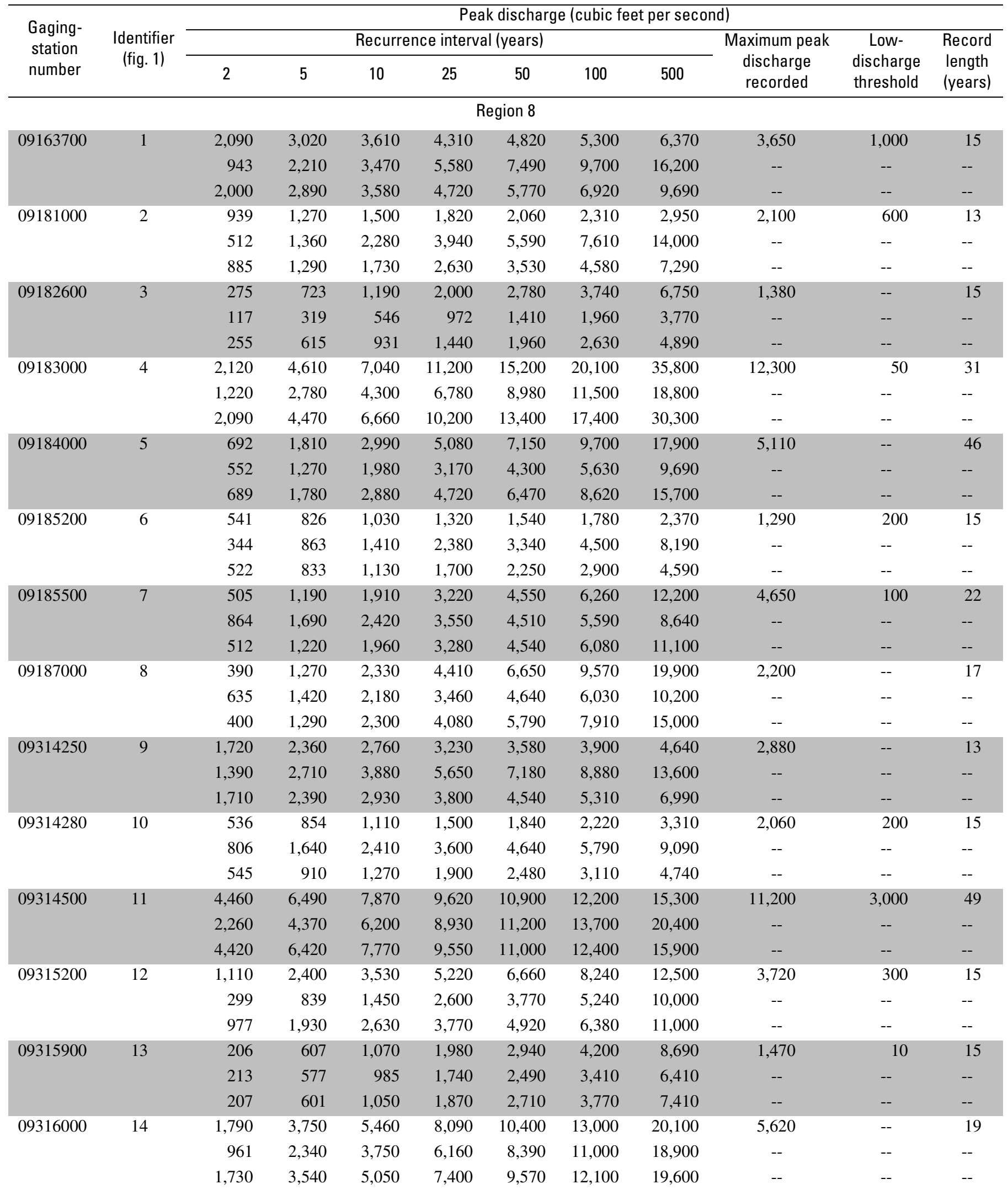




\section{Magnitude and Frequency of Peak Discharges for the Navajo Nation in Arizona, Utah, Colorado, and New Mexico}

Appendix 1. Selected basin, climatic, and flood characteristics, maximum peak discharge recorded and low-discharge threshold for

\begin{tabular}{|c|c|c|c|c|c|}
\hline $\begin{array}{l}\text { Gaging- } \\
\text { station } \\
\text { number }\end{array}$ & $\begin{array}{l}\text { Identifier } \\
\text { (fig. 1) }\end{array}$ & $\begin{array}{l}\text { Gaging-station } \\
\text { name }\end{array}$ & $\begin{array}{l}\text { Drainage } \\
\text { area } \\
\text { (square } \\
\text { miles) }\end{array}$ & $\begin{array}{l}\text { Average } \\
\text { basin slope } \\
\text { (percent) }\end{array}$ & $\begin{array}{l}\text { Average } \\
\text { basin } \\
\text { elevation } \\
\text { (feet) }\end{array}$ \\
\hline \multicolumn{6}{|c|}{ Region 8-Continued } \\
\hline \multirow[t]{2}{*}{09327600} & 15 & Ferron Creek tributary near Ferron, Utah & 0.62 & 0.0793 & 6,180 \\
\hline & & & 0.96 & & \\
\hline \multirow[t]{2}{*}{09328300} & 16 & Sids Draw near Castle Dale, Utah & 18.4 & 0.1393 & 6,400 \\
\hline & & & 17.6 & & \\
\hline \multirow[t]{2}{*}{09328600} & 17 & Georges Draw near Hanksville, Utah & 6.95 & 0.1126 & 6,940 \\
\hline & & & 6.63 & & \\
\hline \multirow[t]{2}{*}{09330120} & 19 & Sulphur Creek near Fruita, Utah & 54.0 & 0.2344 & 6,980 \\
\hline & & & 56.7 & & \\
\hline \multirow[t]{2}{*}{09330200} & 20 & Pleasant Creek at Notom, Utah & 78.5 & 0.2334 & 7,400 \\
\hline & & & 80.6 & & \\
\hline \multirow[t]{2}{*}{09330300} & 21 & Neilson Wash near Caineville, Utah & 22.5 & 0.0730 & 4,790 \\
\hline & & & 22.3 & & \\
\hline \multirow[t]{2}{*}{09336400} & 24 & Upper Valley Creek near Escalante, Utah & 53.9 & 0.2187 & 7,520 \\
\hline & & & 53.0 & & \\
\hline \multirow[t]{2}{*}{09338900} & 25 & Deer Creek near Boulder, Utah & 65.4 & 0.2127 & 7,360 \\
\hline & & & 62.7 & & \\
\hline \multirow[t]{2}{*}{09339200} & 26 & Twentymile Wash near Escalante, Utah & 144 & 0.2699 & 6,460 \\
\hline & & & 140 & & \\
\hline \multirow[t]{2}{*}{09357200} & 27 & Gallegos Canyon tributary near Nageezi, New Mexico & 0.060 & 0.0231 & 6,650 \\
\hline & & & 0.200 & & \\
\hline \multirow[t]{2}{*}{09357230} & 28 & West Draw near Farmington, New Mexico & 0.29 & 0.0491 & 5,980 \\
\hline & & & 0.32 & & \\
\hline
\end{tabular}


gaging stations in flood regions 8,11 , high elevation, and 6 -Continued.

\begin{tabular}{|c|c|c|c|c|c|c|c|c|c|c|c|}
\hline \multirow{3}{*}{$\begin{array}{l}\text { Gaging- } \\
\text { station } \\
\text { number }\end{array}$} & \multirow{3}{*}{$\begin{array}{c}\text { Identifier } \\
\text { (fig. 1) }\end{array}$} & \multicolumn{10}{|c|}{ Peak discharge (cubic feet per second) } \\
\hline & & \multicolumn{7}{|c|}{ Recurrence interval (years) } & \multirow{2}{*}{$\begin{array}{c}\text { Maximum peak } \\
\text { discharge } \\
\text { recorded }\end{array}$} & \multirow{2}{*}{$\begin{array}{c}\text { Low- } \\
\text { discharge } \\
\text { threshold }\end{array}$} & \multirow{2}{*}{$\begin{array}{l}\text { Record } \\
\text { length } \\
\text { (years) }\end{array}$} \\
\hline & & 2 & 5 & 10 & 25 & 50 & 100 & 500 & & & \\
\hline \multicolumn{12}{|c|}{ Region 8-Continued } \\
\hline \multirow[t]{3}{*}{09327600} & 15 & 111 & 341 & 607 & 1,110 & 1,630 & 2,290 & 4,530 & 600 & -- & 12 \\
\hline & & 64 & 180 & 312 & 569 & 841 & 1,190 & 2,400 & -- & -- & -- \\
\hline & & 104 & 289 & 467 & 774 & 1,100 & 1,520 & 3,020 & -- & -- & -- \\
\hline \multirow[t]{3}{*}{09328300} & 16 & 464 & 1,300 & 2,120 & 3,450 & 4,630 & 5,970 & 9,620 & 2,150 & 170 & 14 \\
\hline & & 301 & 725 & 1,160 & 1,920 & 2,660 & 3,550 & 6,320 & -- & -- & -- \\
\hline & & 450 & 1,180 & 1,810 & 2,730 & 3,580 & 4,600 & 7,780 & -- & -- & -- \\
\hline \multirow[t]{3}{*}{09328600} & 17 & 210 & 587 & 1,010 & 1,830 & 2,690 & 3,800 & 7,750 & 1,650 & 10 & 15 \\
\hline & & 163 & 398 & 644 & 1,090 & 1,520 & 2,060 & 3,790 & -- & -- & -- \\
\hline & & 206 & 548 & 890 & 1,470 & 2,040 & 2,770 & 5,320 & -- & -- & -- \\
\hline \multirow[t]{3}{*}{09328700} & 18 & 139 & 381 & 671 & 1,270 & 1,940 & 2,890 & 6,680 & 1,880 & 30 & 10 \\
\hline & & 555 & 1,290 & 2,040 & 3,290 & 4,440 & 5,790 & 9,850 & -- & -- & -- \\
\hline & & 159 & 494 & 976 & 2,010 & 3,060 & 4,330 & 8,400 & -- & -- & -- \\
\hline \multirow[t]{3}{*}{09330120} & 19 & 688 & 1,310 & 1,860 & 2,700 & 3,450 & 4,300 & 6,790 & 2,600 & 350 & 16 \\
\hline & & 475 & 1,100 & 1,720 & 2,780 & 3,780 & 4,980 & 8,620 & -- & -- & -- \\
\hline & & 671 & 1,280 & 1,820 & 2,730 & 3,600 & 4,620 & 7,640 & -- & -- & -- \\
\hline \multirow[t]{3}{*}{09330200} & 20 & 238 & 793 & 1,470 & 2,800 & 4,220 & 6,080 & 12,600 & 2,040 & -- & 14 \\
\hline & & 502 & 1,120 & 1,730 & 2,740 & 3,690 & 4,810 & 8,190 & -- & -- & -- \\
\hline & & 250 & 837 & 1,530 & 2,780 & 3,970 & 5,430 & 10,200 & -- & -- & -- \\
\hline \multirow[t]{3}{*}{09330300} & 21 & 1,140 & 2,250 & 3,220 & 4,720 & 6,050 & 7,550 & 11,800 & 5,450 & 350 & 15 \\
\hline & & 453 & 1,100 & 1,770 & 2,920 & 4,000 & 5,280 & 9,190 & -- & -- & -- \\
\hline & & 1,070 & 2,030 & 2,780 & 3,950 & 5,050 & 6,390 & 10,500 & -- & -- & -- \\
\hline \multirow[t]{3}{*}{09330400} & 22 & 4,510 & 7,050 & 9,050 & 12,000 & 14,400 & 17,100 & 24,700 & 15,300 & 2,000 & 15 \\
\hline & & 1,850 & 3,420 & 4,760 & 6,720 & 8,340 & 10,100 & 14,900 & -- & -- & -- \\
\hline & & 4,390 & 6,660 & 8,280 & 10,500 & 12,400 & 14,600 & 21,100 & -- & -- & -- \\
\hline \multirow[t]{3}{*}{09334000} & 23 & 1,180 & 3,070 & 5,010 & 8,420 & 11,700 & 15,800 & 28,500 & 8,900 & -- & 21 \\
\hline & & 1,230 & 2,920 & 4,630 & 7,480 & 10,100 & 13,100 & 22,200 & -- & -- & -- \\
\hline & & 1,180 & 3,050 & 4,940 & 8,140 & 11,100 & 14,700 & 25,900 & -- & -- & -- \\
\hline \multirow[t]{3}{*}{09336400} & 24 & 719 & 1,580 & 2,440 & 3,950 & 5,440 & 7,320 & 13,600 & 5,560 & -- & 16 \\
\hline & & 409 & 925 & 1,430 & 2,290 & 3,100 & 4,070 & 7,020 & -- & -- & -- \\
\hline & & 696 & 1,470 & 2,170 & 3,280 & 4,340 & 5,660 & 10,100 & -- & -- & -- \\
\hline \multirow[t]{3}{*}{09338900} & 25 & 392 & 1,250 & 2,290 & 4,370 & 6,630 & 9,650 & 20,600 & 3,820 & 50 & 16 \\
\hline & & 457 & 1,030 & 1,580 & 2,520 & 3,400 & 4,440 & 7,590 & -- & -- & -- \\
\hline & & 396 & 1,210 & 2,100 & 3,570 & 4,960 & 6,720 & 12,800 & -- & -- & -- \\
\hline \multirow[t]{3}{*}{09339200} & 26 & 1,750 & 2,910 & 3,820 & 5,100 & 6,210 & 7,390 & 10,600 & 4,620 & 1,000 & 10 \\
\hline & & 859 & 1,940 & 3,000 & 4,740 & 6,350 & 8,210 & 13,800 & -- & -- & -- \\
\hline & & 1,650 & 2,690 & 3,540 & 4,950 & 6,280 & 7,830 & 12,200 & -- & -- & -- \\
\hline 09357200 & 27 & 108 & 205 & 291 & 425 & 546 & 686 & 1,100 & 580 & 25 & 35 \\
\hline & & 15 & 42 & 74 & 138 & 209 & 303 & 641 & -- & -- & -- \\
\hline & & 94 & 160 & 206 & 281 & 364 & 475 & 858 & -- & -- & -- \\
\hline 09357230 & 28 & 23 & 38 & 49 & 64 & 76 & 88 & 119 & 54 & -- & 21 \\
\hline & & 43 & 122 & 213 & 393 & 585 & 837 & 1,710 & -- & -- & -- \\
\hline & & 24 & 47 & 77 & 143 & 214 & 296 & 510 & -- & -- & -- \\
\hline
\end{tabular}




\section{Magnitude and Frequency of Peak Discharges for the Navajo Nation in Arizona, Utah, Colorado, and New Mexico}

Appendix 1. Selected basin, climatic, and flood characteristics, maximum peak discharge recorded and low-discharge threshold for

\begin{tabular}{|c|c|c|c|c|c|}
\hline $\begin{array}{l}\text { Gaging- } \\
\text { station } \\
\text { number }\end{array}$ & $\begin{array}{l}\text { Identifier } \\
\text { (fig. 1) }\end{array}$ & $\begin{array}{l}\text { Gaging-station } \\
\text { name }\end{array}$ & $\begin{array}{c}\text { Drainage } \\
\text { area } \\
\text { (square } \\
\text { miles) }\end{array}$ & $\begin{array}{c}\text { Average } \\
\text { basin slope } \\
\text { (percent) }\end{array}$ & $\begin{array}{l}\text { Average } \\
\text { basin } \\
\text { elevation } \\
\text { (feet) }\end{array}$ \\
\hline \multicolumn{6}{|c|}{ Region 8-Continued } \\
\hline 09367530 & 29 & Locke Arroyo near Kirtland, New Mexico & $\begin{array}{l}2.68 \\
2.96\end{array}$ & 0.0720 & 5,500 \\
\hline 09367550 & 30 & Stevens Arroyo near Kirtland, New Mexico & $\begin{array}{l}4.72 \\
4.59\end{array}$ & 0.0569 & 5,490 \\
\hline 09367561 & 31 & Shumway Arroyo near Waterflow, New Mexico & $\begin{array}{c}134 \\
73.8\end{array}$ & 0.1109 & 5,640 \\
\hline 09367900 & 33 & Black springs Wash near Mexican Springs, New Mexico & $\begin{array}{l}7.13 \\
7.05\end{array}$ & 0.1513 & 6,690 \\
\hline 09367930 & 34 & Hunter Wash at Bisti Trading Post, New Mexico & $\begin{array}{l}45.0 \\
45.6\end{array}$ & 0.0494 & 6,200 \\
\hline 09367950 & 35 & Chaco River near Waterflow, New Mexico & $\begin{array}{l}4,350 \\
4,350\end{array}$ & 0.0681 & 6,290 \\
\hline 09371000 & 38 & Mancos River near Towaoc, Colorado & $\begin{array}{l}523 \\
526\end{array}$ & 0.2422 & 6,940 \\
\hline 09378480 & 39 & Montezuma Creek near Monticello, Utah & $\begin{array}{l}142 \\
117\end{array}$ & 0.1209 & 7,030 \\
\hline 09378950 & 40 & Comb Wash near Blanding, Utah & $\begin{array}{l}10.3 \\
10.3\end{array}$ & 0.2549 & 5,810 \\
\hline 09379000 & 41 & Comb Wash near Bluff, Utah & $\begin{array}{l}276 \\
278\end{array}$ & 0.2009 & 5,880 \\
\hline 09379030 & 42 & Black Mountain Wash near Chinle, Arizona & $\begin{array}{l}73.5 \\
80.7\end{array}$ & 0.1031 & 5,830 \\
\hline
\end{tabular}


gaging stations in flood regions 8,11 , high elevation, and 6 -Continued.

\begin{tabular}{|c|c|c|c|c|c|c|c|c|c|c|c|}
\hline \multirow{3}{*}{$\begin{array}{l}\text { Gaging- } \\
\text { station } \\
\text { number }\end{array}$} & \multirow{3}{*}{$\begin{array}{c}\text { Identifier } \\
\text { (fig. 1) }\end{array}$} & \multicolumn{10}{|c|}{ Peak discharge (cubic feet per second) } \\
\hline & & \multicolumn{7}{|c|}{ Recurrence interval (years) } & \multirow{2}{*}{$\begin{array}{c}\text { Maximum peak } \\
\text { discharge } \\
\text { recorded }\end{array}$} & \multirow{2}{*}{$\begin{array}{c}\text { Low- } \\
\text { discharge } \\
\text { threshold }\end{array}$} & \multirow{2}{*}{$\begin{array}{l}\text { Record } \\
\text { length } \\
\text { (years) }\end{array}$} \\
\hline & & 2 & 5 & 10 & 25 & 50 & 100 & 500 & & & \\
\hline \multicolumn{12}{|c|}{ Region 8-Continued } \\
\hline \multirow[t]{3}{*}{09367530} & 29 & 94 & 248 & 408 & 684 & 949 & 1,270 & 2,260 & 535 & -- & 35 \\
\hline & & 143 & 377 & 634 & 1,110 & 1,590 & 2,190 & 4,140 & -- & -- & -- \\
\hline & & 95 & 259 & 441 & 785 & 1,130 & 1,550 & 2,840 & -- & -- & -- \\
\hline \multirow[t]{3}{*}{09367550} & 30 & 134 & 470 & 901 & 1,800 & 2,800 & 4,160 & 9,250 & 1,550 & 10 & 21 \\
\hline & & 171 & 429 & 704 & 1,200 & 1,680 & 2,280 & 4,180 & -- & -- & -- \\
\hline & & 136 & 464 & 853 & 1,570 & 2,280 & 3,210 & 6,530 & -- & -- & -- \\
\hline \multirow[t]{3}{*}{09367561} & 31 & 183 & 783 & 1,680 & 3,820 & 6,500 & 10,500 & 27,800 & 6,420 & 10 & 16 \\
\hline & & 821 & 1,800 & 2,730 & 4,250 & 5,610 & 7,160 & 11,700 & -- & -- & -- \\
\hline & & 197 & 861 & 1,850 & 3,950 & 6,150 & 8,990 & 19,500 & -- & -- & -- \\
\hline \multirow[t]{3}{*}{09367860} & 32 & 1,260 & 2,430 & 3,470 & 5,130 & 6,650 & 8,430 & 13,800 & 6,400 & 600 & 29 \\
\hline & & 203 & 504 & 819 & 1,390 & 1,950 & 2,650 & 4,890 & -- & -- & -- \\
\hline & & 1,150 & 2,020 & 2,610 & 3,420 & 4,240 & 5,310 & 9,060 & -- & -- & -- \\
\hline \multirow[t]{3}{*}{09367900} & 33 & 446 & 1,000 & 1,530 & 2,430 & 3,270 & 4,280 & 7,390 & 2,250 & -- & 44 \\
\hline & & 191 & 481 & 789 & 1,350 & 1,910 & 2,600 & 4,820 & -- & -- & -- \\
\hline & & 428 & 919 & 1,340 & 2,020 & 2,680 & 3,500 & 6,210 & -- & -- & -- \\
\hline \multirow[t]{3}{*}{09367930} & 34 & 752 & 1,200 & 1,510 & 1,900 & 2,200 & 2,500 & 3,190 & 1,570 & -- & 18 \\
\hline & & 348 & 742 & 1,120 & 1,740 & 2,300 & 2,950 & 4,880 & -- & -- & -- \\
\hline & & 730 & 1,140 & 1,430 & 1,860 & 2,230 & 2,640 & 3,700 & -- & -- & -- \\
\hline \multirow[t]{3}{*}{09367950} & 35 & 3,880 & 5,270 & 6,190 & 7,350 & 8,220 & 9,090 & 11,100 & 7,300 & 2,500 & 30 \\
\hline & & 2,610 & 4,440 & 5,930 & 7,980 & 9,540 & 11,200 & 15,500 & -- & -- & -- \\
\hline & & 3,870 & 5,250 & 6,180 & 7,410 & 8,360 & 9,330 & 11,600 & -- & -- & -- \\
\hline \multirow[t]{3}{*}{09367980} & 36 & 143 & 568 & 1,230 & 2,900 & 5,150 & 8,780 & 26,900 & 3,800 & -- & 17 \\
\hline & & 300 & 670 & 1,040 & 1,650 & 2,210 & 2,870 & 4,840 & -- & -- & -- \\
\hline & & 149 & 579 & 1,190 & 2,440 & 3,790 & 5,660 & 13,600 & -- & -- & -- \\
\hline \multirow[t]{3}{*}{09368020} & 37 & 57 & 127 & 194 & 307 & 412 & 539 & 932 & 321 & -- & 16 \\
\hline & & 125 & 331 & 559 & 981 & 1,410 & 1,940 & 3,690 & -- & -- & -- \\
\hline & & 63 & 160 & 288 & 558 & 840 & 1,180 & 2,180 & -- & -- & -- \\
\hline \multirow[t]{3}{*}{09371000} & 38 & 1,110 & 1,920 & 2,570 & 3,510 & 4,300 & 5,150 & 7,450 & 5,300 & 60 & 66 \\
\hline & & 1,270 & 2,620 & 3,850 & 5,770 & 7,450 & 9,350 & 14,800 & -- & -- & -- \\
\hline & & 1,110 & 1,940 & 2,620 & 3,660 & 4,560 & 5,530 & 8,090 & -- & -- & -- \\
\hline \multirow[t]{3}{*}{09378480} & 39 & 475 & 1,140 & 1,790 & 2,900 & 3,960 & 5,240 & 9,220 & 1,720 & -- & 10 \\
\hline & & 587 & 1,220 & 1,820 & 2,770 & 3,630 & 4,610 & 7,500 & -- & -- & -- \\
\hline & & 486 & 1,160 & 1,800 & 2,840 & 3,770 & 4,850 & 8,110 & -- & -- & -- \\
\hline \multirow[t]{3}{*}{09378950} & 40 & 746 & 1,440 & 2,090 & 3,150 & 4,150 & 5,350 & 9,160 & 3,430 & 100 & 10 \\
\hline & & 330 & 879 & 1,480 & 2,580 & 3,680 & 5,040 & 9,440 & -- & -- & -- \\
\hline & & 673 & 1,260 & 1,810 & 2,820 & 3,850 & 5,150 & 9,340 & -- & -- & -- \\
\hline 09379000 & 41 & 1,760 & 3,160 & 4,410 & 6,400 & 8,230 & 10,400 & 17,100 & 8,390 & 1,150 & 10 \\
\hline & & 1,230 & 2,680 & 4,060 & 6,280 & 8,240 & 10,500 & 17,000 & -- & -- & -- \\
\hline & & 1,710 & 3,070 & 4,300 & 6,350 & 8,240 & 10,400 & 17,000 & -- & -- & -- \\
\hline 09379030 & 42 & 892 & 1,630 & 2,220 & 3,060 & 3,760 & 4,510 & 6,480 & 3,100 & 450 & 15 \\
\hline & & 588 & 1,310 & 2,020 & 3,180 & 4,240 & 5,470 & 9,130 & -- & -- & -- \\
\hline & & 871 & 1,580 & 2,170 & 3,100 & 3,950 & 4,910 & 7,540 & -- & -- & -- \\
\hline
\end{tabular}




\section{Magnitude and Frequency of Peak Discharges for the Navajo Nation in Arizona, Utah, Colorado, and New Mexico}

Appendix 1. Selected basin, climatic, and flood characteristics, maximum peak discharge recorded and low-discharge threshold for

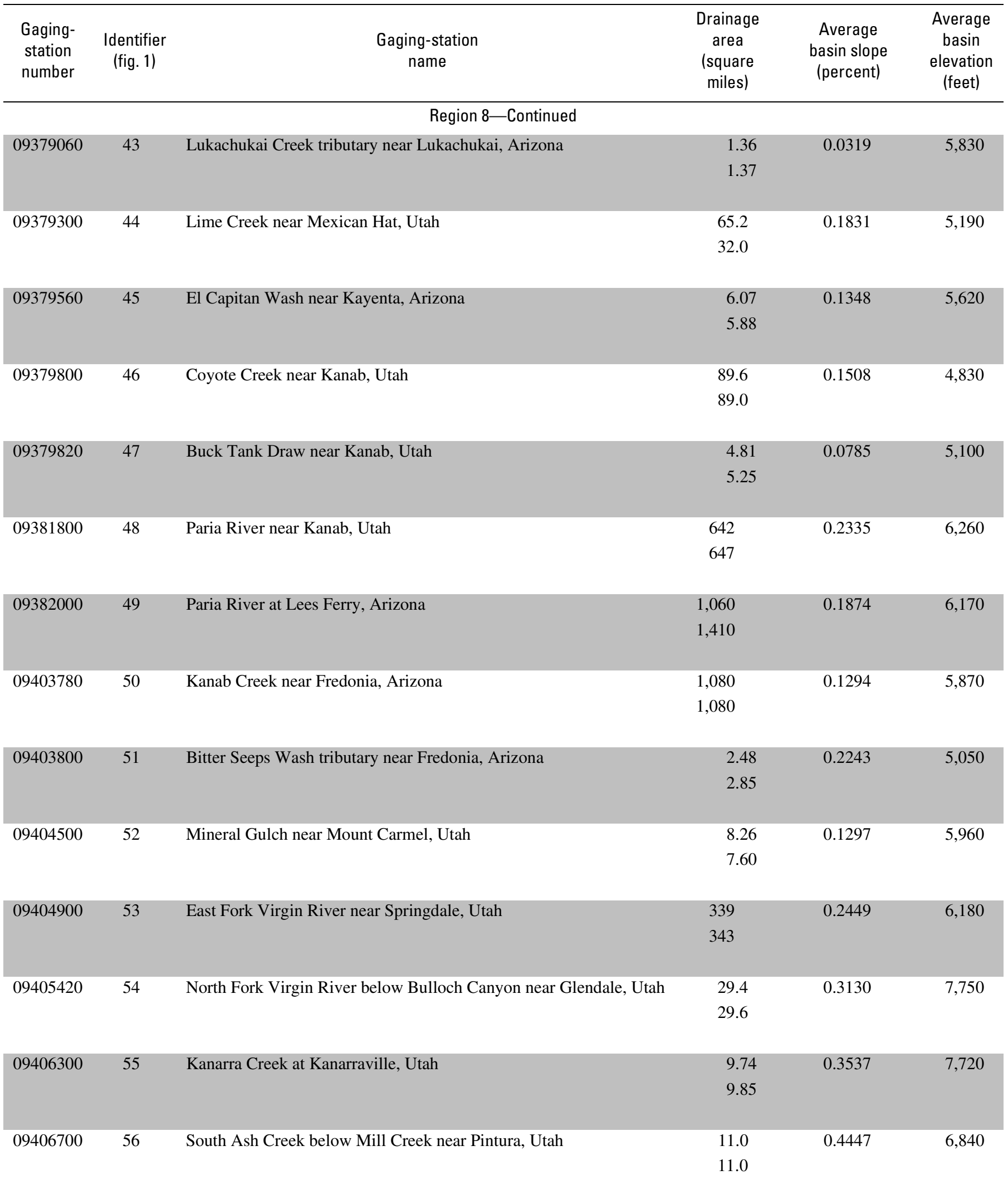


gaging stations in flood regions 8,11 , high elevation, and 6 -Continued.

\begin{tabular}{|c|c|c|c|c|c|c|c|c|c|c|c|}
\hline \multirow{3}{*}{$\begin{array}{l}\text { Gaging- } \\
\text { station } \\
\text { number }\end{array}$} & \multirow{3}{*}{$\begin{array}{l}\text { Identifier } \\
\text { (fig. 1) }\end{array}$} & \multicolumn{10}{|c|}{ Peak discharge (cubic feet per second) } \\
\hline & & \multicolumn{7}{|c|}{ Recurrence interval (years) } & \multirow{2}{*}{$\begin{array}{l}\text { Maximum peak } \\
\text { discharge } \\
\text { recorded }\end{array}$} & \multirow{2}{*}{$\begin{array}{c}\text { Low- } \\
\text { discharge } \\
\text { threshold }\end{array}$} & \multirow{2}{*}{$\begin{array}{l}\text { Record } \\
\text { length } \\
\text { (years) }\end{array}$} \\
\hline & & 2 & 5 & 10 & 25 & 50 & 100 & 500 & & & \\
\hline \multicolumn{12}{|c|}{ Region 8-Continued } \\
\hline \multirow[t]{3}{*}{09379060} & 43 & 20 & 46 & 74 & 126 & 182 & 255 & 522 & 49 & 12 & 14 \\
\hline & & 77 & 195 & 322 & 557 & 792 & 1,090 & 2,050 & -- & -- & -- \\
\hline & & 23 & 61 & 117 & 245 & 384 & 557 & 1,100 & -- & -- & -- \\
\hline \multirow[t]{3}{*}{09379300} & 44 & 1,680 & 4,150 & 6,560 & 10,500 & 14,200 & 18,600 & 31,400 & 6,600 & 100 & 15 \\
\hline & & 804 & 1,940 & 3,100 & 5,070 & 6,900 & 9,060 & 15,600 & -- & -- & -- \\
\hline & & 1,600 & 3,700 & 5,430 & 7,980 & 10,300 & 13,200 & 22,300 & -- & -- & -- \\
\hline \multirow[t]{3}{*}{09379560} & 45 & 469 & 950 & 1,390 & 2,110 & 2,780 & 3,570 & 5,980 & 2,340 & -- & 14 \\
\hline & & 233 & 613 & 1,030 & 1,790 & 2,550 & 3,490 & 6,520 & -- & -- & -- \\
\hline & & 440 & 869 & 1,260 & 1,950 & 2,650 & 3,520 & 6,290 & -- & -- & -- \\
\hline \multirow[t]{3}{*}{09379800} & 46 & 1,410 & 2,740 & 3,850 & 5,490 & 6,870 & 8,390 & 12,500 & 4,590 & 100 & 14 \\
\hline & & 985 & 2,340 & 3,700 & 5,990 & 8,080 & 10,500 & 17,700 & -- & -- & -- \\
\hline & & 1,370 & 2,680 & 3,810 & 5,670 & 7,380 & 9,330 & 14,700 & -- & -- & -- \\
\hline \multirow[t]{3}{*}{09379820} & 47 & 10 & 70 & 208 & 685 & 1,510 & 3,100 & 13,900 & 680 & -- & 10 \\
\hline & & 215 & 561 & 939 & 1,630 & 2,310 & 3,150 & 5,860 & -- & -- & -- \\
\hline & & 14 & 124 & 387 & 1,110 & 1,970 & 3,140 & 7,860 & -- & -- & -- \\
\hline \multirow[t]{3}{*}{09381800} & 48 & 2,480 & 5,290 & 7,960 & 12,400 & 16,600 & 21,700 & 37,600 & 15,400 & -- & 17 \\
\hline & & 1,650 & 3,420 & 5,050 & 7,590 & 9,780 & 12,200 & 19,200 & -- & -- & -- \\
\hline & & 2,430 & 5,050 & 7,310 & 10,700 & 13,800 & 17,400 & 28,900 & -- & -- & -- \\
\hline \multirow[t]{3}{*}{09382000} & 49 & 3,450 & 6,320 & 8,750 & 12,500 & 15,700 & 19,400 & 29,900 & 16,100 & 1,000 & 76 \\
\hline & & 1,970 & 3,920 & 5,670 & 8,320 & 10,500 & 13,000 & 19,800 & -- & -- & -- \\
\hline & & 3,430 & 6,260 & 8,610 & 12,100 & 15,200 & 18,600 & 28,700 & -- & -- & -- \\
\hline \multirow[t]{3}{*}{09403780} & 50 & 871 & 1,780 & 2,620 & 3,970 & 5,220 & 6,700 & 11,200 & 4,630 & 100 & 16 \\
\hline & & 1,950 & 3,820 & 5,470 & 7,950 & 10,000 & 12,200 & 18,400 & -- & -- & -- \\
\hline & & 896 & 1,900 & 2,920 & 4,690 & 6,310 & 8,130 & 13,200 & -- & -- & -- \\
\hline \multirow[t]{3}{*}{09403800} & 51 & 129 & 560 & 1,190 & 2,640 & 4,380 & 6,890 & 17,000 & 1,950 & -- & 14 \\
\hline & & 222 & 652 & 1,160 & 2,130 & 3,150 & 4,460 & 8,850 & -- & -- & -- \\
\hline & & 139 & 586 & 1,180 & 2,330 & 3,550 & 5,160 & 11,000 & -- & -- & -- \\
\hline \multirow[t]{3}{*}{09404500} & 52 & 315 & 931 & 1,650 & 3,050 & 4,540 & 6,500 & 13,500 & 3,210 & 30 & 14 \\
\hline & & 238 & 604 & 995 & 1,700 & 2,400 & 3,250 & 5,990 & -- & -- & -- \\
\hline & & 307 & 857 & 1,410 & 2,340 & 3,260 & 4,440 & 8,590 & -- & -- & -- \\
\hline \multirow[t]{3}{*}{09404900} & 53 & 1,050 & 2,600 & 4,110 & 6,590 & 8,880 & 11,600 & 19,400 & 3,540 & -- & 8 \\
\hline & & 1,300 & 2,820 & 4,240 & 6,530 & 8,560 & 10,900 & 17,500 & -- & -- & -- \\
\hline & & 1,070 & 2,640 & 4,150 & 6,570 & 8,730 & 11,200 & 18,400 & -- & -- & -- \\
\hline \multirow[t]{3}{*}{09405420} & 54 & 203 & 406 & 603 & 943 & 1,280 & 1,690 & 3,090 & 1,740 & -- & 11 \\
\hline & & 331 & 791 & 1,260 & 2,070 & 2,870 & 3,840 & 6,880 & -- & -- & -- \\
\hline & & 212 & 465 & 765 & 1,360 & 1,960 & 2,680 & 4,860 & -- & -- & -- \\
\hline 09406300 & 55 & 141 & 367 & 608 & 1,050 & 1,490 & 2,050 & 3,920 & 1,000 & -- & 23 \\
\hline & & 216 & 552 & 910 & 1,570 & 2,230 & 3,060 & 5,770 & -- & -- & -- \\
\hline & & 145 & 387 & 663 & 1,190 & 1,740 & 2,420 & 4,620 & -- & -- & -- \\
\hline 09406700 & 56 & 219 & 523 & 839 & 1,410 & 1,980 & 2,700 & 5,160 & 1,910 & 60 & 16 \\
\hline & & 299 & 797 & 1,340 & 2,340 & 3,360 & 4,630 & 8,780 & -- & -- & -- \\
\hline & & 225 & 566 & 966 & 1,760 & 2,580 & 3,600 & 6,870 & -- & -- & -- \\
\hline
\end{tabular}




\section{Magnitude and Frequency of Peak Discharges for the Navajo Nation in Arizona, Utah, Colorado, and New Mexico}

Appendix 1. Selected basin, climatic, and flood characteristics, maximum peak discharge recorded and low-discharge threshold for

\begin{tabular}{|c|c|c|c|c|c|}
\hline $\begin{array}{l}\text { Gaging- } \\
\text { station } \\
\text { number }\end{array}$ & $\begin{array}{l}\text { Identifier } \\
\text { (fig. 1) }\end{array}$ & $\begin{array}{l}\text { Gaging-station } \\
\text { name }\end{array}$ & $\begin{array}{l}\text { Drainage } \\
\text { area } \\
\text { (square } \\
\text { miles) }\end{array}$ & $\begin{array}{c}\text { Average } \\
\text { basin slope } \\
\text { (percent) }\end{array}$ & $\begin{array}{c}\text { Average } \\
\text { basin } \\
\text { elevation } \\
\text { (feet) }\end{array}$ \\
\hline \multicolumn{6}{|c|}{ Region 8-Continued } \\
\hline 09406800 & 57 & South Ash Creek near Pintura, Utah & $\begin{array}{l}13.7 \\
14.0\end{array}$ & 0.4152 & 6,590 \\
\hline 09407200 & 58 & Ash Creek below West Field Ditch at Toquerville, Utah & $\begin{array}{l}200 \\
201\end{array}$ & 0.2998 & 5,920 \\
\hline 09408000 & 59 & Leeds Creek near Leeds, Utah & $\begin{array}{l}15.3 \\
15.5\end{array}$ & 0.3708 & 6,130 \\
\hline 09409100 & 61 & Santa Clara River above Baker Reservoir near Central, Utah & $\begin{array}{l}111 \\
116\end{array}$ & 0.2783 & 7,230 \\
\hline 09409500 & 62 & Moody Wash near Veyo, Utah & $\begin{array}{l}33.5 \\
33.0\end{array}$ & 0.2953 & 6,010 \\
\hline
\end{tabular}

Region 11

\begin{tabular}{|c|c|c|c|c|}
\hline 09385800 & 63 & Little Colorado River tributary near St. Johns, Arizona & $\begin{array}{l}0.35 \\
0.35\end{array}$ & 0.0985 \\
\hline 09386200 & 64 & Carrizo Creek near Salt Lake, New Mexico & $\begin{array}{r}1,820 \\
560\end{array}$ & 0.0827 \\
\hline 09386950 & 65 & Zuni River above Black Rock Reservoir, New Mexico & $\begin{array}{l}831 \\
848\end{array}$ & 0.0874 \\
\hline 09387050 & 66 & Galestena Canyon tributary near Black Rock, New Mexico & $\begin{array}{l}18.5 \\
19.0\end{array}$ & 0.0729 \\
\hline 09390500 & 67 & Show Low Creek near Lakeside, Arizona & $\begin{array}{l}67.9 \\
68.6\end{array}$ & 0.0579 \\
\hline 09395200 & 69 & Decker Wash near Snowflake, Arizona & $\begin{array}{l}15.8 \\
16.5\end{array}$ & 0.0640 \\
\hline 09395500 & 70 & Puerco River at Gallup, New Mexico & $\begin{array}{l}548 \\
558\end{array}$ & 0.1106 \\
\hline
\end{tabular}


gaging stations in flood regions 8,11 , high elevation, and 6 -Continued.

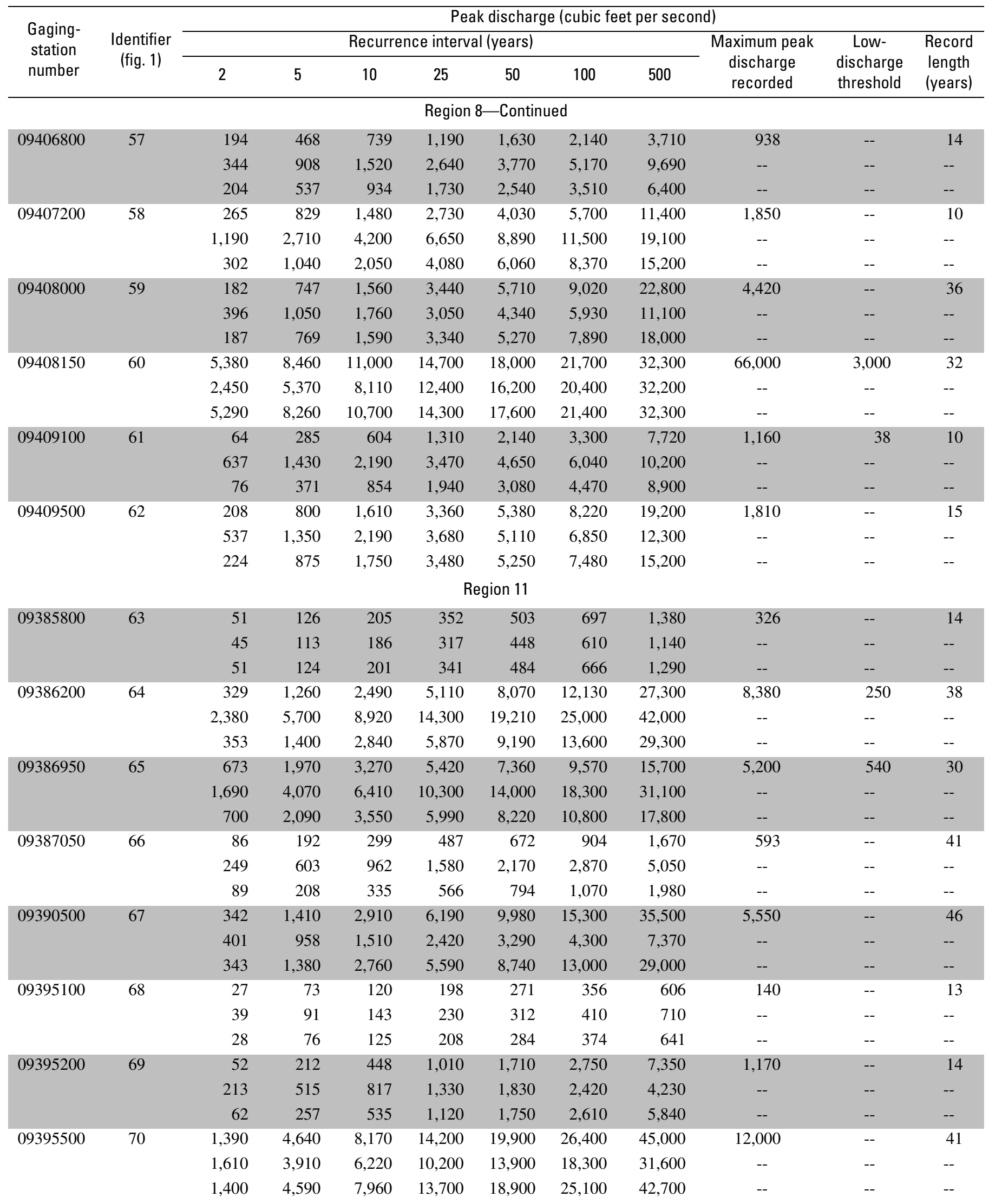




\section{Magnitude and Frequency of Peak Discharges for the Navajo Nation in Arizona, Utah, Colorado, and New Mexico}

Appendix 1. Selected basin, climatic, and flood characteristics, maximum peak discharge recorded and low-discharge threshold for

\begin{tabular}{|c|c|c|c|c|c|}
\hline $\begin{array}{l}\text { Gaging- } \\
\text { station } \\
\text { number }\end{array}$ & $\begin{array}{l}\text { Identifier } \\
\text { (fig. 1) }\end{array}$ & $\begin{array}{l}\text { Gaging-station } \\
\text { name }\end{array}$ & $\begin{array}{l}\text { Drainage } \\
\text { area } \\
\text { (square } \\
\text { miles) }\end{array}$ & $\begin{array}{l}\text { Average } \\
\text { basin slope } \\
\text { (percent) }\end{array}$ & $\begin{array}{c}\text { Average } \\
\text { basin } \\
\text { elevation } \\
\text { (feet) }\end{array}$ \\
\hline \multicolumn{6}{|c|}{ Region 11-Continued } \\
\hline \multirow[t]{2}{*}{09395600} & 71 & Wagon Trail Wash near Gamerco, New Mexico & 0.28 & 0.0451 & \\
\hline & & & 0.38 & & \\
\hline \multirow[t]{2}{*}{09395900} & 72 & Black Creek near Lupton, Arizona & 491 & 0.1188 & \\
\hline & & & 493 & & \\
\hline \multirow[t]{2}{*}{09396100} & 73 & Puerco River near Chambers, Arizona & 2,150 & 0.0976 & \\
\hline & & & 2,160 & & \\
\hline \multirow[t]{2}{*}{09397100} & 75 & Leroux Wash near Holbrook, Arizona & 806 & 0.0471 & \\
\hline & & & 809 & & \\
\hline \multirow[t]{2}{*}{09397500} & 76 & Chevelon Fork below Wildcat Canyon, near Winslow, Arizona & 270 & 0.1132 & \\
\hline & & & 275 & & \\
\hline \multirow[t]{2}{*}{09397800} & 77 & Brookbank Canyon near Heber, Arizona & 27.5 & 0.0802 & \\
\hline & & & 27.9 & & \\
\hline \multirow[t]{2}{*}{09400100} & 80 & Ganado Wash tributary near Ganado, Arizona & 8.89 & 0.0379 & \\
\hline & & & 7.85 & & \\
\hline \multirow[t]{2}{*}{09400200} & 81 & Steamboat Wash tributary near Ganado, Arizona & 0.156 & 0.0863 & \\
\hline & & & 0.320 & & \\
\hline \multirow[t]{2}{*}{09400290} & 82 & Teshbito Wash tributary near Holbrook, Arizona & 19.8 & 0.0675 & \\
\hline & & & 20.0 & & \\
\hline \multirow[t]{2}{*}{09400300} & 83 & Teshbito Wash near Holbrook, Arizona & 68.0 & 0.0690 & \\
\hline & & & 60.3 & & \\
\hline \multirow[t]{2}{*}{09400530} & 84 & Cow Canyon near Winslow, Arizona & 6.25 & 0.0177 & \\
\hline & & & 7.53 & & \\
\hline
\end{tabular}


gaging stations in flood regions 8,11 , high elevation, and 6 -Continued.

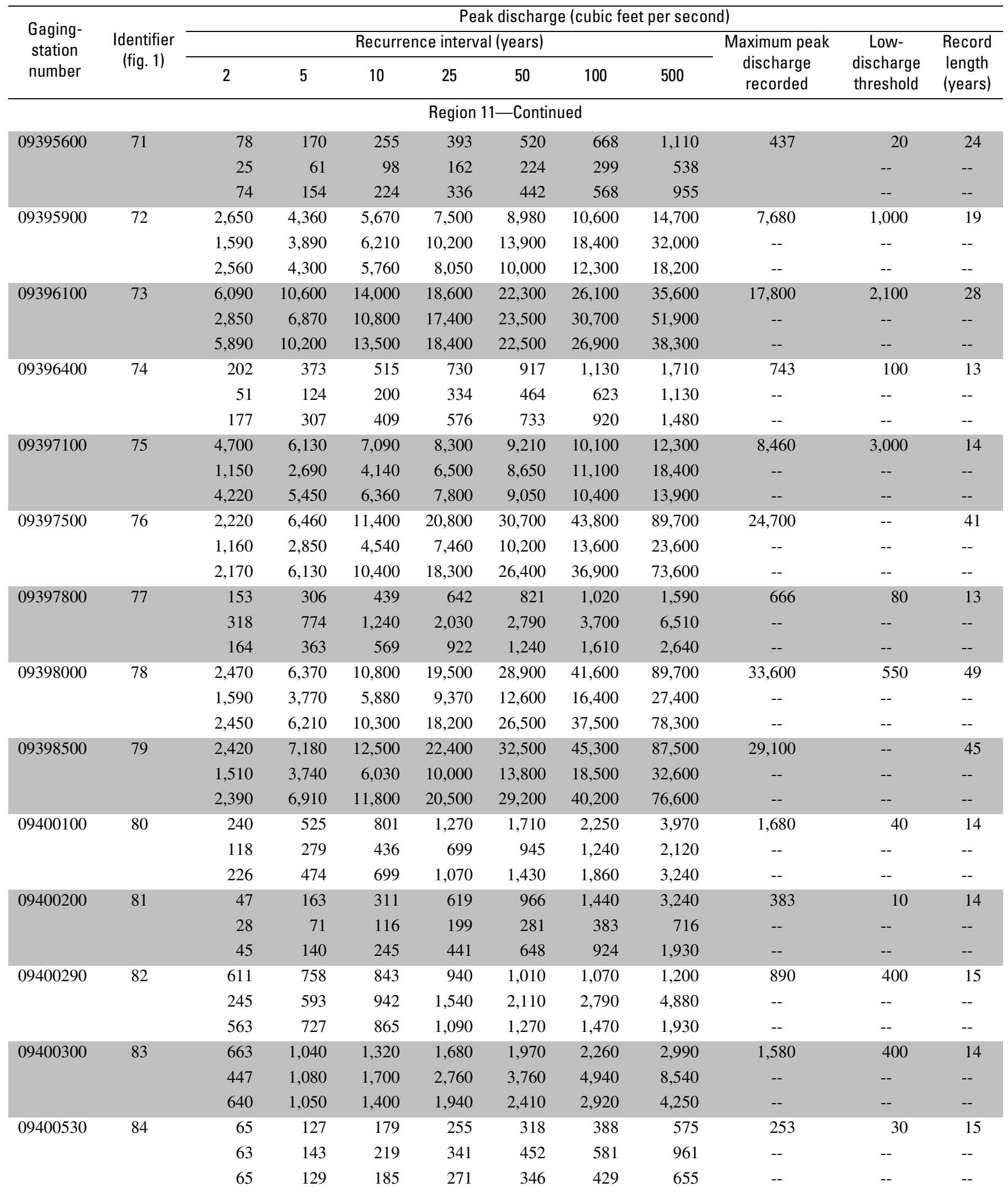




\section{Magnitude and Frequency of Peak Discharges for the Navajo Nation in Arizona, Utah, Colorado, and New Mexico}

Appendix 1. Selected basin, climatic, and flood characteristics, maximum peak discharge recorded and low-discharge threshold for

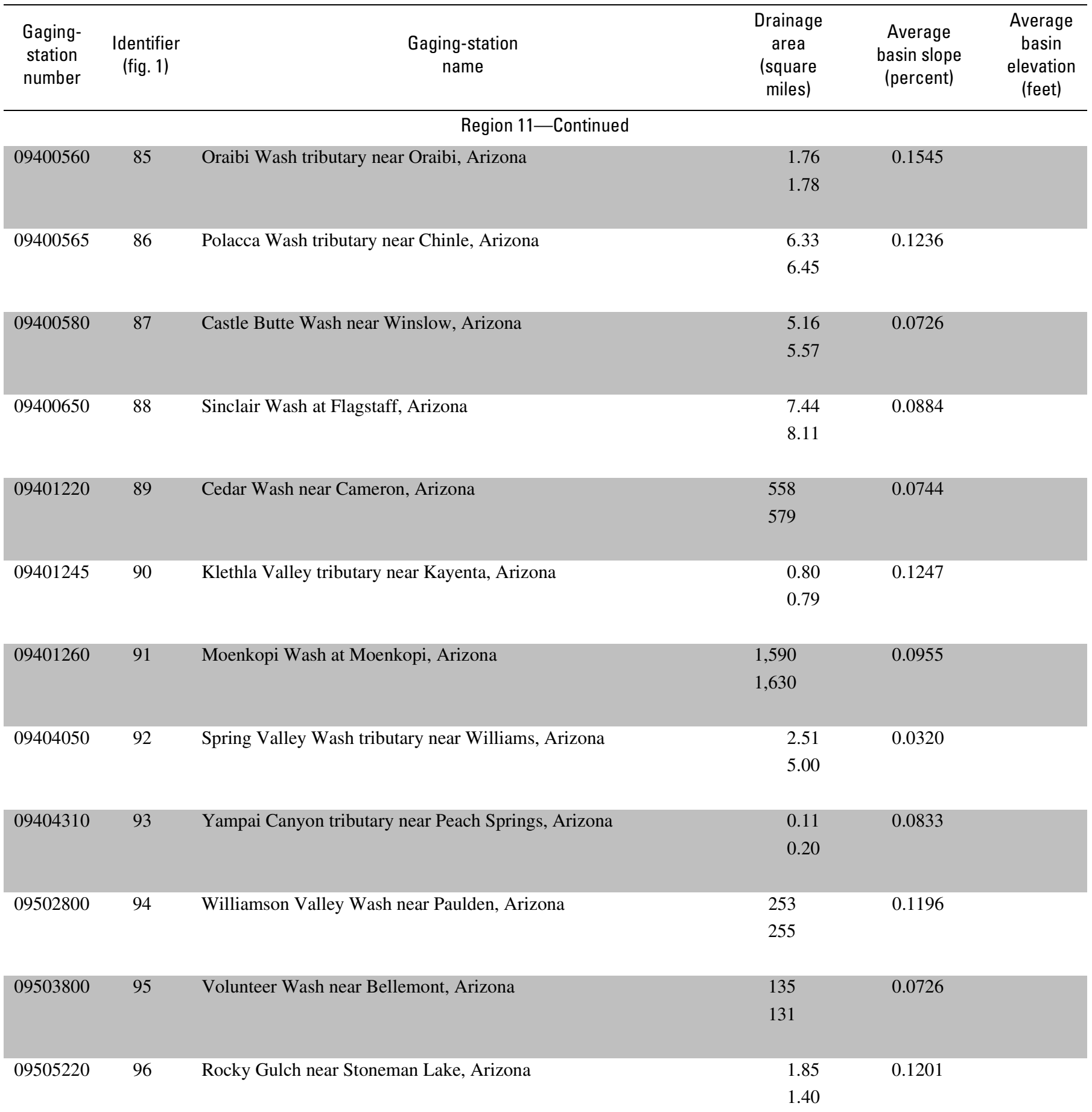

Region High Elevation

$\begin{array}{llll}09177500 & 97 & \text { Taylor Creek near Gateway, Colorado, } & 15.3 \\ & & 12.0 \\ 09183500 & 98 & \text { Mill Creek at Sheley Tunnel near Moab, Utah } & 26.4 \\ \end{array}$


gaging stations in flood regions 8,11 , high elevation, and 6 -Continued.

\begin{tabular}{|c|c|c|c|c|c|c|c|c|c|c|c|}
\hline \multirow{3}{*}{$\begin{array}{l}\text { Gaging- } \\
\text { station } \\
\text { number }\end{array}$} & \multirow{3}{*}{$\begin{array}{c}\text { Identifier } \\
\text { (fig. 1) }\end{array}$} & \multicolumn{10}{|c|}{ Peak discharge (cubic feet per second) } \\
\hline & & \multicolumn{7}{|c|}{ Recurrence interval (years) } & \multirow{2}{*}{$\begin{array}{l}\text { Maximum peak } \\
\text { discharge } \\
\text { recorded }\end{array}$} & \multirow{2}{*}{$\begin{array}{c}\text { Low- } \\
\text { discharge } \\
\text { threshold }\end{array}$} & \multirow{2}{*}{$\begin{array}{l}\text { Record } \\
\text { length } \\
\text { (years) }\end{array}$} \\
\hline & & 2 & 5 & 10 & 25 & 50 & 100 & 500 & & & \\
\hline \multicolumn{12}{|c|}{ Region 11-Continued } \\
\hline \multirow[t]{3}{*}{09400560} & 85 & 124 & 237 & 333 & 481 & 609 & 755 & 1,170 & 383 & 30 & 14 \\
\hline & & 128 & 325 & 538 & 926 & 1,310 & 1,800 & 3,370 & -- & -- & -- \\
\hline & & 125 & 250 & 373 & 583 & 778 & 1,000 & 1,660 & -- & -- & -- \\
\hline \multirow[t]{3}{*}{09400565} & 86 & 365 & 707 & 985 & 1,390 & 1,720 & 2,080 & 3,010 & 1,130 & 200 & 13 \\
\hline & & 206 & 514 & 839 & 1,420 & 1,990 & 2,680 & 4,910 & -- & -- & -- \\
\hline & & 344 & 666 & 945 & 1,400 & 1,810 & 2,270 & 3,590 & -- & -- & -- \\
\hline \multirow[t]{3}{*}{09400580} & 87 & 86 & 283 & 523 & 1,000 & 1,520 & 2,200 & 4,630 & 707 & 10 & 13 \\
\hline & & 135 & 330 & 529 & 875 & 1,210 & 1,610 & 2,870 & -- & -- & -- \\
\hline & & 91 & 292 & 525 & 955 & 1,390 & 1,950 & 3,840 & -- & -- & -- \\
\hline \multirow[t]{3}{*}{09400650} & 88 & 74 & 166 & 258 & 416 & 571 & 762 & 1,380 & 401 & -- & 11 \\
\hline & & 181 & 446 & 718 & 1,200 & 1,660 & 2,220 & 3,980 & -- & -- & -- \\
\hline & & 82 & 205 & 346 & 604 & 857 & 1,160 & 2,110 & -- & -- & -- \\
\hline \multirow[t]{3}{*}{09401220} & 89 & 1,510 & 4,460 & 7,840 & 14,200 & 20,900 & 29,500 & 59,000 & 10,400 & 100 & 10 \\
\hline & & 1,270 & 3,050 & 4,780 & 7,670 & 10,400 & 13,500 & 22,900 & -- & -- & -- \\
\hline & & 1,480 & 4,120 & 6,800 & 11,400 & 16,000 & 21,700 & 40,400 & -- & -- & -- \\
\hline \multirow[t]{3}{*}{09401245} & 90 & 121 & 191 & 241 & 307 & 359 & 412 & 543 & 290 & 60 & 15 \\
\hline & & 77 & 195 & 322 & 551 & 780 & 1,070 & 1,990 & -- & -- & -- \\
\hline & & 117 & 192 & 257 & 362 & 454 & 556 & 824 & -- & -- & -- \\
\hline \multirow[t]{3}{*}{09401260} & 91 & 3,450 & 5,730 & 7,470 & 9,900 & 11,900 & 14,000 & 19,400 & 10,100 & 1,300 & 26 \\
\hline & & 2,440 & 5,870 & 9,240 & 14,900 & 20,200 & 26,300 & 44,700 & -- & -- & -- \\
\hline & & 3,390 & 5,750 & 7,690 & 10,600 & 13,100 & 15,900 & 23,000 & -- & -- & -- \\
\hline \multirow[t]{3}{*}{09404050} & 92 & 20 & 58 & 101 & 182 & 266 & 374 & 745 & 35 & -- & 14 \\
\hline & & 58 & 137 & 215 & 345 & 468 & 613 & 1,060 & -- & -- & -- \\
\hline & & 22 & 67 & 120 & 218 & 316 & 438 & 835 & -- & -- & -- \\
\hline \multirow[t]{3}{*}{09404310} & 93 & 14 & 36 & 62 & 110 & 161 & 229 & 473 & 177 & -- & 13 \\
\hline & & 24 & 59 & 97 & 165 & 233 & 318 & 596 & -- & -- & -- \\
\hline & & 15 & 40 & 70 & 127 & 185 & 260 & 519 & -- & -- & -- \\
\hline \multirow[t]{3}{*}{09502800} & 94 & 1,300 & 4,070 & 7,390 & 13,900 & 21,000 & 30,300 & 63,600 & 14,800 & -- & 21 \\
\hline & & 1,170 & 2,860 & 4,580 & 7,540 & 10,400 & 13,700 & 24,100 & -- & -- & -- \\
\hline & & 1,290 & 3,900 & 6,810 & 12,200 & 17,700 & 24,900 & 49,700 & -- & -- & -- \\
\hline \multirow[t]{3}{*}{09503800} & 95 & 507 & 1,130 & 1,670 & 2,500 & 3,200 & 3,980 & 6,060 & 2,300 & 200 & 14 \\
\hline & & 638 & 1,540 & 2,420 & 3,920 & 5,330 & 7,000 & 12,000 & -- & -- & -- \\
\hline & & 519 & 1,200 & 1,840 & 2,890 & 3,820 & 4,880 & 7,800 & -- & -- & -- \\
\hline \multirow[t]{3}{*}{09505220} & 96 & 38 & 122 & 235 & 490 & 804 & 1,270 & 3,380 & 1,550 & 10 & 30 \\
\hline & & 113 & 283 & 463 & 788 & 1,110 & 1,510 & 2,790 & -- & -- & -- \\
\hline & & 40 & 132 & 256 & 530 & 853 & 1,320 & 3,260 & -- & -- & -- \\
\hline & & & & & Region & igh Elev & & & & & \\
\hline 09177500 & 97 & 111 & 264 & 407 & 637 & 843 & 1,080 & 1,770 & 555 & -- & 24 \\
\hline & & 88 & 196 & 299 & 471 & 631 & 822 & 1,410 & -- & -- & -- \\
\hline & & 108 & 245 & 368 & 566 & 748 & 964 & 1,610 & -- & -- & -- \\
\hline 09183500 & 98 & 197 & 452 & 710 & 1,170 & 1,620 & 2,190 & 4,080 & 1,080 & -- & 17 \\
\hline & & 134 & 288 & 433 & 670 & 887 & 1,140 & 1,910 & -- & -- & -- \\
\hline & & 186 & 400 & 594 & 919 & 1,230 & 1,620 & 2,880 & -- & -- & -- \\
\hline
\end{tabular}




\section{Magnitude and Frequency of Peak Discharges for the Navajo Nation in Arizona, Utah, Colorado, and New Mexico}

Appendix 1. Selected basin, climatic, and flood characteristics, maximum peak discharge recorded and low-discharge threshold for

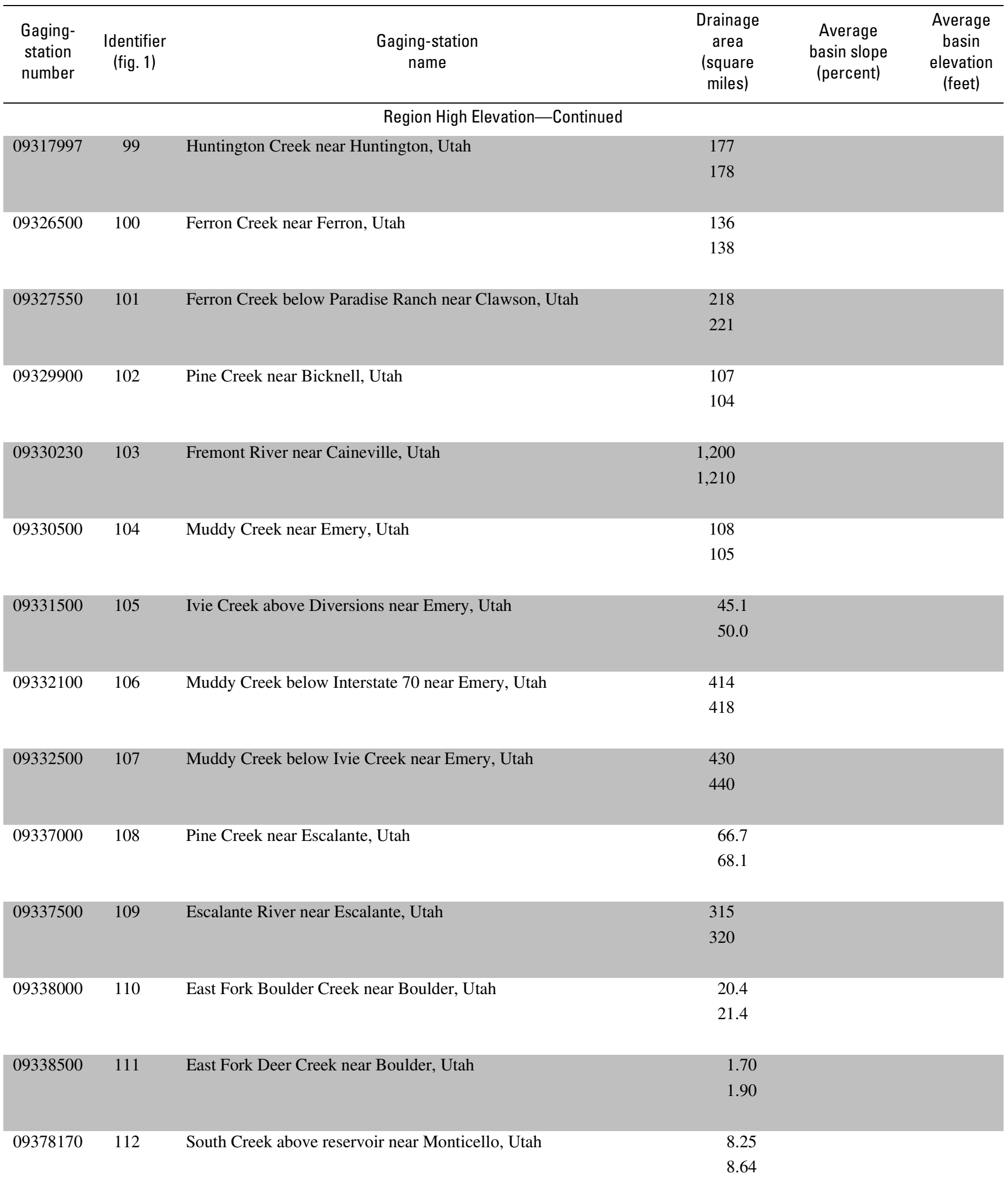


gaging stations in flood regions 8,11 , high elevation, and 6 -Continued.

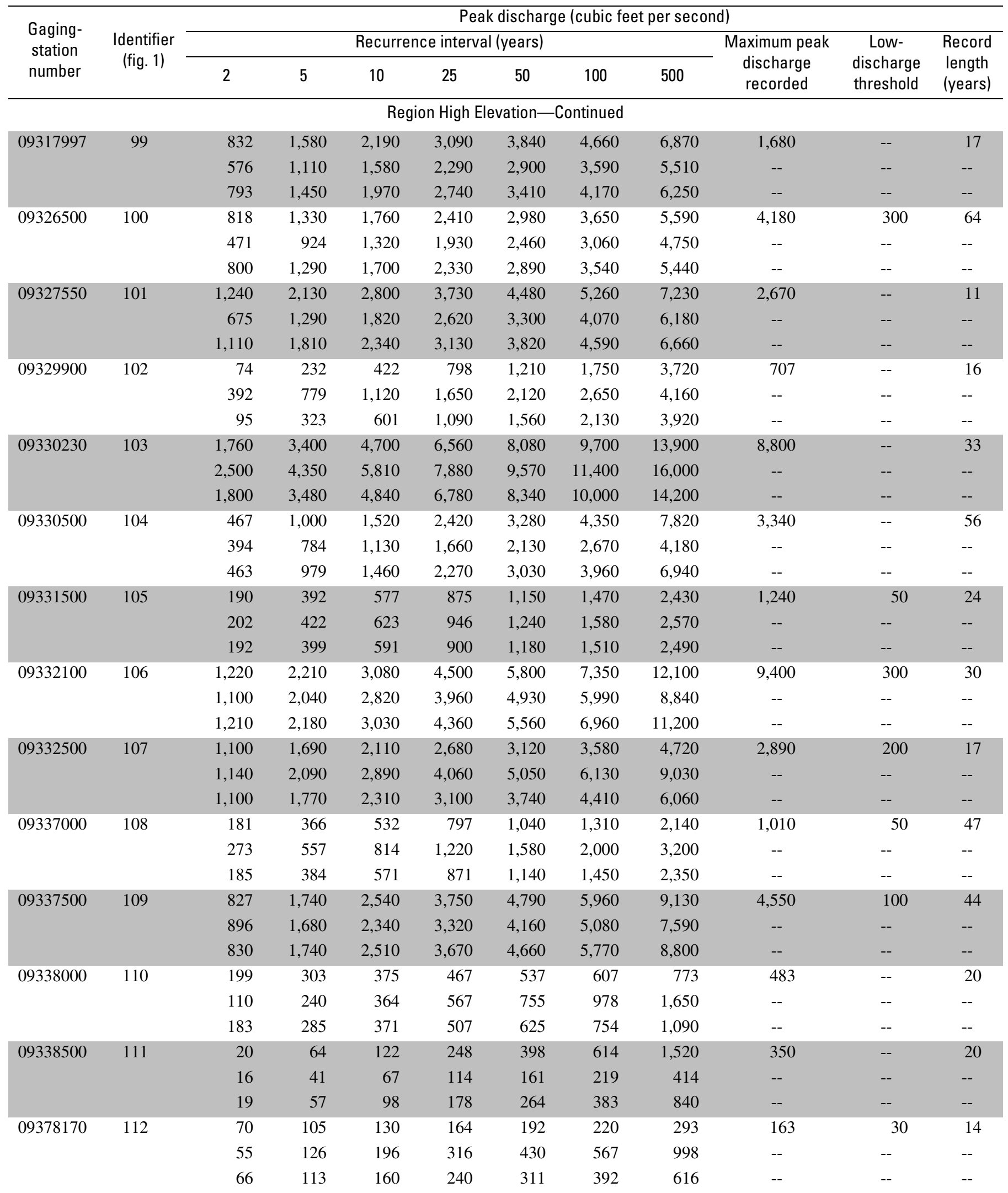


Appendix 1. Selected basin, climatic, and flood characteristics, maximum peak discharge recorded and low-discharge threshold for

\begin{tabular}{|c|c|c|c|c|c|}
\hline $\begin{array}{l}\text { Gaging- } \\
\text { station } \\
\text { number }\end{array}$ & $\begin{array}{l}\text { Identifier } \\
\text { (fig. 1) }\end{array}$ & $\begin{array}{c}\text { Gaging-station } \\
\text { name }\end{array}$ & $\begin{array}{c}\text { Drainage } \\
\text { area } \\
\text { (square } \\
\text { miles) }\end{array}$ & $\begin{array}{l}\text { Average } \\
\text { basin slope } \\
\text { (percent) }\end{array}$ & $\begin{array}{c}\text { Average } \\
\text { basin } \\
\text { elevation } \\
\text { (feet) }\end{array}$ \\
\hline
\end{tabular}

\begin{tabular}{rrrr}
\hline & & \multicolumn{2}{c}{ Region High Elevation-Continued } \\
09378630 & 113 & Recapture Creek near Blanding, Utah & 3.88 \\
& & & 3.77 \\
09378650 & 114 & Recapture Creek below Johnson Creek near Blanding, Utah & 37.1 \\
& & & 50.2
\end{tabular}

\begin{tabular}{rrlr}
09383600 & 115 & Fish Creek near Eager, Arizona & 17.0 \\
& & & 16.9 \\
09386100 & \multirow{2}{*}{116} & Largo Creek near Quemado, New Mexico & 138 \\
& & & 151
\end{tabular}

\begin{tabular}{rrrr}
09386900 & 117 & Rio Nutria near Ramah, New Mexico & 71.2 \\
& & & 71.4 \\
09408400 & \multirow{2}{*}{118} & Santa Clara River near Pine Valley, Utah & 18.3 \\
& & & 18.7
\end{tabular}

\begin{tabular}{|c|c|c|c|}
\hline 09442650 & 119 & Romero Creek near Arizona State line near Luna, New Mexico & $\begin{array}{c}9.37 \\
10.8\end{array}$ \\
\hline 09489200 & 120 & Pacheta Creek near Maverick, Arizona & $\begin{array}{l}16.4 \\
14.8\end{array}$ \\
\hline
\end{tabular}

$\begin{array}{lccc}09489700 & 121 & \text { Big Bonito Creek near Fort Apache, Arizona } & 114 \\ 119 \\ 09490800 & 122 & \text { North Fork White River near Greer, Arizona } & 39.3 \\ & & & 40.2\end{array}$

$\begin{array}{llll}09491000 & 123 & \text { North Fork White River near McNary, Arizona } & 69.1 \\ & 78.2\end{array}$

\section{Region 6}

$\begin{array}{lll}08313100 & \text { Canada Ancha tributary near Santa Fe, New Mexico } & 0.577\end{array}$

$\begin{array}{llll}08316600 & 125 & \text { North Frijoles Arroyo near Santa Fe, New Mexico } & 0.356 \\ 0.330\end{array}$


gaging stations in flood regions 8,11 , high elevation, and 6 -Continued.

\begin{tabular}{|c|c|c|c|c|c|c|c|c|c|c|c|}
\hline \multirow{3}{*}{$\begin{array}{l}\text { Gaging- } \\
\text { station } \\
\text { number }\end{array}$} & \multirow{3}{*}{$\begin{array}{l}\text { Identifier } \\
\text { (fig. 1) }\end{array}$} & \multicolumn{10}{|c|}{ Peak discharge (cubic feet per second) } \\
\hline & & \multicolumn{7}{|c|}{ Recurrence interval (years) } & \multirow{2}{*}{$\begin{array}{l}\text { Maximum peak } \\
\text { discharge } \\
\text { recorded }\end{array}$} & \multirow{2}{*}{$\begin{array}{c}\text { Low- } \\
\text { discharge } \\
\text { threshold }\end{array}$} & \multirow{2}{*}{$\begin{array}{l}\text { Record } \\
\text { length } \\
\text { (years) }\end{array}$} \\
\hline & & 2 & 5 & 10 & 25 & 50 & 100 & 500 & & & \\
\hline \multicolumn{12}{|c|}{ Region High Elevation-Continued } \\
\hline \multirow[t]{3}{*}{09378630} & 113 & 15 & 36 & 58 & 99 & 139 & 191 & 364 & 97 & 1 & 34 \\
\hline & & 31 & 74 & 118 & 194 & 269 & 360 & 655 & -- & -- & -- \\
\hline & & 16 & 41 & 69 & 121 & 171 & 234 & 439 & -- & -- & -- \\
\hline \multirow[t]{3}{*}{09378650} & 114 & 120 & 330 & 546 & 914 & 1,260 & 1,670 & 2,890 & 695 & -- & 18 \\
\hline & & 174 & 367 & 546 & 834 & 1,100 & 1,400 & 2,310 & -- & -- & -- \\
\hline & & 127 & 340 & 546 & 877 & 1,180 & 1,530 & 2,590 & -- & -- & -- \\
\hline \multirow[t]{3}{*}{09383600} & 115 & 62 & 163 & 258 & 408 & 539 & 684 & 1,070 & 236 & 50 & 13 \\
\hline & & 96 & 211 & 321 & 504 & 674 & 876 & 1,490 & -- & -- & -- \\
\hline & & 68 & 180 & 287 & 458 & 613 & 790 & 1,300 & -- & -- & -- \\
\hline \multirow[t]{3}{*}{09386100} & 116 & 313 & 552 & 761 & 1,090 & 1,390 & 1,740 & 2,800 & 1,320 & 250 & 42 \\
\hline & & 476 & 934 & 1,330 & 1,950 & 2,490 & 3,090 & 4,790 & -- & -- & -- \\
\hline & & 335 & 644 & 944 & 1,420 & 1,840 & 2,310 & 3,640 & -- & -- & -- \\
\hline \multirow[t]{3}{*}{09386900} & 117 & 338 & 676 & 954 & 1,360 & 1,700 & 2,070 & 3,030 & 1,840 & -- & 30 \\
\hline & & 287 & 583 & 851 & 1,270 & 1,650 & 2,080 & 3,310 & -- & -- & -- \\
\hline & & 333 & 659 & 928 & 1,330 & 1,680 & 2,070 & 3,120 & -- & -- & -- \\
\hline \multirow{3}{*}{09408400} & 118 & 87 & 209 & 342 & 597 & 869 & 1,230 & 2,570 & 340 & -- & 40 \\
\hline & & 101 & 222 & 338 & 528 & 706 & 916 & 1,550 & -- & -- & -- \\
\hline & & 90 & 214 & 340 & 557 & 768 & 1,030 & 1,900 & -- & -- & -- \\
\hline \multirow[t]{3}{*}{09442650} & 119 & 56 & 145 & 244 & 436 & 643 & 918 & 1,940 & 480 & -- & 19 \\
\hline & & 61 & 138 & 214 & 343 & 465 & 612 & 1,070 & -- & -- & -- \\
\hline & & 57 & 143 & 231 & 388 & 545 & 744 & 1,430 & -- & -- & -- \\
\hline \multirow[t]{3}{*}{09489200} & 120 & 105 & 179 & 234 & 312 & 374 & 439 & 607 & 312 & 20 & 23 \\
\hline & & 93 & 205 & 313 & 492 & 659 & 858 & 1,460 & -- & -- & -- \\
\hline & & 104 & 185 & 258 & 372 & 472 & 583 & 878 & -- & -- & -- \\
\hline \multirow[t]{3}{*}{09489700} & 121 & 644 & 1,510 & 2,370 & 3,840 & 5,240 & 6,950 & 12,300 & 4,510 & -- & 24 \\
\hline & & 411 & 815 & 1,170 & 1,720 & 2,210 & 2,750 & 4,310 & -- & -- & -- \\
\hline & & 615 & 1,340 & 1,960 & 2,930 & 3,850 & 4,950 & 8,400 & -- & -- & -- \\
\hline \multirow[t]{3}{*}{09490800} & 122 & 188 & 261 & 315 & 390 & 451 & 516 & 689 & 299 & 100 & 13 \\
\hline & & 182 & 382 & 568 & 866 & 1,140 & 1,450 & 2,380 & -- & -- & -- \\
\hline & & 186 & 297 & 408 & 588 & 742 & 911 & 1,360 & -- & -- & -- \\
\hline \multirow[t]{3}{*}{09491000} & 123 & 404 & 740 & 1,030 & 1,480 & 1,890 & 2,350 & 3,720 & 2,310 & -- & 39 \\
\hline & & 280 & 571 & 833 & 1,250 & 1,620 & 2,040 & 3,260 & -- & -- & -- \\
\hline & & 394 & 713 & 987 & 1,420 & 1,810 & 2,260 & 3,590 & -- & -- & -- \\
\hline \multicolumn{12}{|c|}{ Region 6} \\
\hline 08313100 & 124 & 17 & 71 & 147 & 316 & 517 & 802 & 1,940 & 298 & 5 & 32 \\
\hline & & 105 & 255 & 397 & 636 & 860 & 1,130 & 1,940 & -- & -- & -- \\
\hline & & 19 & 80 & 170 & 367 & 588 & 882 & 1,940 & -- & -- & -- \\
\hline 08316600 & 125 & 141 & 242 & 320 & 429 & 518 & 612 & 856 & 360 & 20 & 13 \\
\hline & & 86 & 211 & 330 & 531 & 721 & 948 & 1,640 & -- & -- & -- \\
\hline & & 135 & 236 & 323 & 462 & 590 & 739 & 1,160 & -- & -- & -- \\
\hline 08316650 & 126 & 510 & 1,010 & 1,450 & 2,100 & 2,680 & 3,320 & 5,120 & 1,900 & 40 & 14 \\
\hline & & 153 & 361 & 558 & 884 & 1,190 & 1,550 & 2,650 & -- & -- & -- \\
\hline & & 464 & 864 & 1,160 & 1,590 & 1,980 & 2,440 & 3,820 & -- & -- & -- \\
\hline
\end{tabular}




\section{Magnitude and Frequency of Peak Discharges for the Navajo Nation in Arizona, Utah, Colorado, and New Mexico}

Appendix 1. Selected basin, climatic, and flood characteristics, maximum peak discharge recorded and low-discharge threshold for

\begin{tabular}{ccccc}
\hline $\begin{array}{c}\text { Gaging- } \\
\text { station } \\
\text { number }\end{array}$ & $\begin{array}{c}\text { Identifier } \\
\text { (fig. 1) }\end{array}$ & Gaging-station \\
name & Region 6-Continued & $\begin{array}{c}\text { Drainage } \\
\text { area } \\
\text { (square } \\
\text { miles) }\end{array}$ & $\begin{array}{c}\text { Average } \\
\text { basin slope } \\
\text { (percent) }\end{array}$ & $\begin{array}{c}\text { Average } \\
\text { basin } \\
\text { elevation } \\
\text { (feet) }\end{array}$ \\
\hline & & Arroyo de los Frijoles near Santa Fe, New Mexico & 2.80 \\
08316700 & 127 & & San Cristobal Arroyo near Galisteo, New Mexico & 2.92 \\
08317600 & 128 & & 114 \\
\end{tabular}

$\begin{array}{llll}08317700 & 129 & \text { Tarhole Canyon near Galisteo, New Mexico } & 2.06 \\ & & & 2.15 \\ 08317720 & 130 & \text { Canada de la Cueva near Galisteo, New Mexico } & 1.77 \\ & & & 1.79\end{array}$

$\begin{array}{lcccc}08318000 & 131 & \text { Galisteo Creek at Domingo, New Mexico } & 661 \\ 640 \\ 08318900 & 132 & \text { San Pedro Creek near Golden, New Mexico } & 44.7 \\ & & & 45.2 \\ 08330500 & 133 & \text { Tijeras Arroyo at Albuquerque, New Mexico } & 74.7 & 75.3 \\ 08330600 & 134 & \text { Tijeras Arroyo near Albuquerque, New Mexico } & 134 \\ & & & 128\end{array}$

$\begin{array}{llll}08331100 & 135 & \text { Belen Highline Canal tributary near Los Lunas, New Mexico } & 0.180 \\ 0.160\end{array}$

\begin{tabular}{lcccc}
\hline 08334000 & 137 & Rio Puerco above Arroyo Chico near Guadalupe, New Mexico & 420 \\
420 & 1,360 \\
08340500 & 138 & Arroyo Chico near Guadalupe, New Mexico & 1,390 \\
08343100 & 139 & Grants Canyon at Grants, New Mexico & 11.8 \\
& & & 13.0
\end{tabular}


gaging stations in flood regions 8,11 , high elevation, and 6 -Continued.

\begin{tabular}{|c|c|c|c|c|c|c|c|c|c|c|c|}
\hline \multirow{3}{*}{$\begin{array}{l}\text { Gaging- } \\
\text { station } \\
\text { number }\end{array}$} & \multirow{3}{*}{$\begin{array}{c}\text { Identifier } \\
\text { (fig. 1) }\end{array}$} & \multicolumn{10}{|c|}{ Peak discharge (cubic feet per second) } \\
\hline & & \multicolumn{7}{|c|}{ Recurrence interval (years) } & \multirow{2}{*}{$\begin{array}{c}\text { Maximum peak } \\
\text { discharge } \\
\text { recorded }\end{array}$} & \multirow{2}{*}{$\begin{array}{c}\text { Low- } \\
\text { discharge } \\
\text { threshold }\end{array}$} & \multirow{2}{*}{$\begin{array}{l}\text { Record } \\
\text { length } \\
\text { (years) }\end{array}$} \\
\hline & & 2 & 5 & 10 & 25 & 50 & 100 & 500 & & & \\
\hline \multicolumn{12}{|c|}{ Region 6-Continued } \\
\hline \multirow[t]{3}{*}{08316700} & 127 & 473 & 1,540 & 2,910 & 5,840 & 9,240 & 14,000 & 33,300 & 5,340 & 30 & 14 \\
\hline & & 205 & 475 & 728 & 1,140 & 1,530 & 1,990 & 3,370 & -- & -- & -- \\
\hline & & 444 & 1,290 & 2,130 & 3,500 & 4,790 & 6,420 & 12,200 & -- & -- & -- \\
\hline \multirow[t]{3}{*}{08317600} & 128 & 1,820 & 3,500 & 5,010 & 7,440 & 9,680 & 12,300 & 20,300 & 13,200 & 800 & 40 \\
\hline & & 971 & 2,050 & 3,010 & 4,540 & 5,920 & 7,520 & 12,200 & -- & -- & -- \\
\hline & & 1,800 & 3,420 & 4,830 & 7,040 & 9,050 & 11,400 & 18,600 & -- & -- & -- \\
\hline \multirow[t]{3}{*}{08317700} & 129 & 315 & 731 & 1,120 & 1,740 & 2,310 & 2,960 & 4,840 & 2,440 & 250 & 34 \\
\hline & & 180 & 420 & 647 & 1,020 & 1,370 & 1,780 & 3,030 & -- & -- & -- \\
\hline & & 309 & 703 & 1,050 & 1,600 & 2,080 & 2,640 & 4,300 & -- & -- & -- \\
\hline \multirow[t]{3}{*}{08317720} & 130 & 114 & 255 & 397 & 647 & 896 & 1,210 & 2,250 & 919 & -- & 25 \\
\hline & & 169 & 396 & 611 & 964 & 1,290 & 1,690 & 2,870 & -- & -- & -- \\
\hline & & 117 & 268 & 426 & 711 & 993 & 1,340 & 2,450 & -- & -- & -- \\
\hline \multirow[t]{3}{*}{08318000} & 131 & 6,440 & 11,000 & 14,700 & 20,100 & 24,700 & 29,800 & 43,900 & 22,800 & 2,000 & 29 \\
\hline & & 2,030 & 4,090 & 5,900 & 8,720 & 11,200 & 14,100 & 22,500 & -- & -- & -- \\
\hline & & 6,240 & 10,400 & 13,500 & 18,000 & 21,700 & 25,900 & 38,000 & -- & -- & -- \\
\hline \multirow[t]{3}{*}{08318900} & 132 & 928 & 1,550 & 2,120 & 3,060 & 3,950 & 5,040 & 8,610 & 10,800 & 600 & 44 \\
\hline & & 655 & 1,410 & 2,100 & 3,200 & 4,210 & 5,380 & 8,630 & -- & -- & -- \\
\hline & & 922 & 1,550 & 2,120 & 3,070 & 3,980 & 5,090 & 8,640 & -- & -- & -- \\
\hline \multirow[t]{3}{*}{08330500} & 133 & 702 & 1,870 & 3,070 & 5,150 & 7,140 & 9,530 & 16,900 & 6,500 & 450 & 47 \\
\hline & & 813 & 1,730 & 2,560 & 3,880 & 5,070 & 6,460 & 10,600 & -- & -- & -- \\
\hline & & 704 & 1,870 & 3,040 & 5,000 & 6,840 & 9,020 & 15,600 & -- & -- & -- \\
\hline \multirow[t]{3}{*}{08330600} & 134 & 664 & 1,160 & 1,570 & 2,160 & 2,670 & 3,230 & 4,770 & 2,930 & -- & 45 \\
\hline & & 1,040 & 2,180 & 3,200 & 4,820 & 6,280 & 7,970 & 12,900 & -- & -- & -- \\
\hline & & 670 & 1,190 & 1,640 & 2,330 & 2,950 & 3,640 & 5,550 & -- & -- & -- \\
\hline \multirow[t]{3}{*}{08331100} & 135 & 199 & 310 & 390 & 497 & 580 & 666 & 878 & 480 & -- & 41 \\
\hline & & 65 & 161 & 254 & 412 & 562 & 742 & 1,300 & -- & -- & -- \\
\hline & & 192 & 297 & 373 & 483 & 576 & 680 & 960 & -- & -- & -- \\
\hline \multirow[t]{3}{*}{08331650} & 136 & 369 & 1,090 & 1,970 & 3,780 & 5,820 & 8,660 & 19,800 & 5,600 & -- & 37 \\
\hline & & 605 & 1,310 & 1,960 & 2,990 & 3,930 & 5,020 & 8,260 & -- & -- & -- \\
\hline & & 374 & 1,100 & 1,970 & 3,670 & 5,500 & 7,920 & 16,800 & -- & -- & -- \\
\hline \multirow[t]{3}{*}{08334000} & 137 & 1,890 & 3,070 & 3,900 & 4,970 & 5,780 & 6,590 & 8,490 & 6,940 & 1,000 & 48 \\
\hline & & 1,680 & 3,420 & 4,960 & 7,370 & 9,530 & 12,000 & 19,200 & -- & -- & -- \\
\hline & & 1,890 & 3,090 & 3,950 & 5,140 & 6,080 & 7,070 & 9,480 & -- & -- & -- \\
\hline \multirow[t]{3}{*}{08340500} & 138 & 4,030 & 6,800 & 9,040 & 12,400 & 15,200 & 18,300 & 27,200 & 15,200 & 1,000 & 43 \\
\hline & & 2,750 & 5,430 & 7,770 & 11,400 & 14,600 & 18,300 & 29,000 & -- & -- & -- \\
\hline & & 4,010 & 6,740 & 8,960 & 12,300 & 15,100 & 18,300 & 27,400 & -- & -- & -- \\
\hline 08343100 & 139 & 175 & 508 & 844 & 1,400 & 1,900 & 2,470 & 4,050 & 1,550 & -- & 34 \\
\hline & & 375 & 837 & 1,260 & 1,950 & 2,590 & 3,330 & 5,550 & -- & -- & -- \\
\hline & & 179 & 525 & 879 & 1,470 & 2,010 & 2,630 & 4,360 & -- & -- & -- \\
\hline 08351500 & 140 & 1,420 & 3,070 & 4,560 & 6,880 & 8,950 & 11,300 & 18,000 & 11,000 & -- & 52 \\
\hline & & 4,160 & 8,020 & 11,300 & 16,500 & 21,000 & 26,100 & 40,800 & -- & -- & -- \\
\hline & & 1,440 & 3,160 & 4,750 & 7,320 & 9,630 & 12,300 & 19,700 & -- & -- & -- \\
\hline
\end{tabular}


34 Magnitude and Frequency of Peak Discharges for the Navajo Nation in Arizona, Utah, Colorado, and New Mexico

Appendix 1. Selected basin, climatic, and flood characteristics, maximum peak discharge recorded and low-discharge threshold for

\begin{tabular}{|c|c|c|c|c|c|}
\hline $\begin{array}{l}\text { Gaging- } \\
\text { station } \\
\text { number }\end{array}$ & $\begin{array}{l}\text { Identifier } \\
\text { (fig. 1) }\end{array}$ & $\begin{array}{l}\text { Gaging-station } \\
\text { name }\end{array}$ & $\begin{array}{l}\text { Drainage } \\
\text { area } \\
\text { (square } \\
\text { miles) }\end{array}$ & $\begin{array}{c}\text { Average } \\
\text { basin slope } \\
\text { (percent) }\end{array}$ & $\begin{array}{c}\text { Average } \\
\text { basin } \\
\text { elevation } \\
\text { (feet) }\end{array}$ \\
\hline \multicolumn{6}{|c|}{ Region 6-Continued } \\
\hline \multirow[t]{2}{*}{08352500} & 141 & Rio Puerco at Rio Puerco, New Mexico & 6,130 & & \\
\hline & & & 6,590 & & \\
\hline \multirow[t]{2}{*}{08353000} & 142 & Rio Puerco near Bernardo, New Mexico & 7,220 & & \\
\hline & & & 7,350 & & \\
\hline \multirow[t]{2}{*}{08354000} & 143 & Rio Salado near San Acacia, New Mexico & 1,380 & & \\
\hline & & & 1,380 & & \\
\hline \multirow[t]{2}{*}{08480150} & 145 & White Oaks Canyon near Carrizozo, New Mexico & 35.1 & & \\
\hline & & & 31.0 & & \\
\hline \multirow[t]{2}{*}{08489000} & 146 & Big Draw near Mountainair, New Mexico & 4.08 & & \\
\hline & & & 3.90 & & \\
\hline
\end{tabular}


gaging stations in flood regions 8,11 , high elevation, and 6 -Continued.

\begin{tabular}{|c|c|c|c|c|c|c|c|c|c|c|c|}
\hline \multirow{3}{*}{$\begin{array}{l}\text { Gaging- } \\
\text { station } \\
\text { number }\end{array}$} & \multirow{3}{*}{$\begin{array}{c}\text { Identifier } \\
\text { (fig. 1) }\end{array}$} & \multicolumn{10}{|c|}{ Peak discharge (cubic feet per second) } \\
\hline & & \multicolumn{7}{|c|}{ Recurrence interval (years) } & \multirow{2}{*}{$\begin{array}{l}\text { Maximum peak } \\
\text { discharge } \\
\text { recorded }\end{array}$} & \multirow{2}{*}{$\begin{array}{c}\text { Low- } \\
\text { discharge } \\
\text { threshold }\end{array}$} & \multirow{2}{*}{$\begin{array}{l}\text { Record } \\
\text { length } \\
\text { (years) }\end{array}$} \\
\hline & & 2 & 5 & 10 & 25 & 50 & 100 & 500 & & & \\
\hline \multicolumn{12}{|c|}{ Region 6-Continued } \\
\hline \multirow[t]{3}{*}{08352500} & 141 & 5,180 & 10,300 & 14,900 & 22,500 & 29,600 & 38,000 & 63,800 & 37,700 & -- & 51 \\
\hline & & 5,170 & 9,830 & 13,800 & 20,000 & 25,400 & 31,500 & 48,900 & -- & -- & -- \\
\hline & & 5,180 & 10,300 & 14,900 & 22,400 & 29,200 & 37,300 & 62,000 & -- & -- & -- \\
\hline \multirow[t]{3}{*}{08353000} & 142 & 2,690 & 5,480 & 7,980 & 12,000 & 15,500 & 19,700 & 31,900 & 18,800 & -- & 60 \\
\hline & & 5,540 & 10,500 & 14,700 & 21,200 & 26,900 & 33,400 & 51,700 & -- & -- & -- \\
\hline & & 2,710 & 5,560 & 8,150 & 12,300 & 16,100 & 20,500 & 33,300 & -- & -- & -- \\
\hline \multirow[t]{3}{*}{08354000} & 143 & 7,250 & 15,100 & 21,300 & 30,000 & 36,800 & 44,000 & 61,200 & 36,200 & 1,000 & 38 \\
\hline & & 2,770 & 5,470 & 7,820 & 11,500 & 14,700 & 18,400 & 29,100 & -- & -- & -- \\
\hline & & 7,120 & 14,500 & 20,000 & 27,300 & 33,000 & 39,100 & 54,500 & -- & -- & -- \\
\hline \multirow[t]{3}{*}{08358600} & 144 & 79 & 223 & 362 & 582 & 774 & 987 & 1,550 & 620 & -- & 35 \\
\hline & & 119 & 285 & 443 & 706 & 953 & 1,250 & 2,140 & -- & -- & -- \\
\hline & & 80 & 227 & 370 & 601 & 807 & 1,040 & 1,680 & -- & -- & -- \\
\hline \multirow[t]{3}{*}{08480150} & 145 & 1,110 & 1,980 & 2,770 & 4,050 & 5,250 & 6,690 & 11,300 & 7,690 & -- & 39 \\
\hline & & 592 & 1,290 & 1,920 & 2,930 & 3,850 & 4,930 & 8,110 & -- & -- & -- \\
\hline & & 1,090 & 1,940 & 2,690 & 3,900 & 5,030 & 6,380 & 10,600 & -- & -- & -- \\
\hline \multirow[t]{3}{*}{08489000} & 146 & 45 & 182 & 370 & 773 & 1,230 & 1,850 & 4,170 & 1,710 & 30 & 40 \\
\hline & & 240 & 550 & 841 & 1,320 & 1,760 & 2,280 & 3,840 & -- & -- & -- \\
\hline & & 47 & 195 & 401 & 835 & 1,310 & 1,930 & 4,100 & -- & -- & -- \\
\hline
\end{tabular}


Blank Page 
Appendix 2-Basin and Climatic

Characteristics Determined Using

Geographical Information System Weasel 
Blank Page 
Appendix 2. Basin and climatic characteristics determined using Geographical Information System Weasel (U.S. Geological Survey, 2000).

[NOAA2, NOAA14, National Oceanic and Atmospheric Administration Atlases 2 and 14, respectively; NAVD88, North American Vertical Datum of 1988]

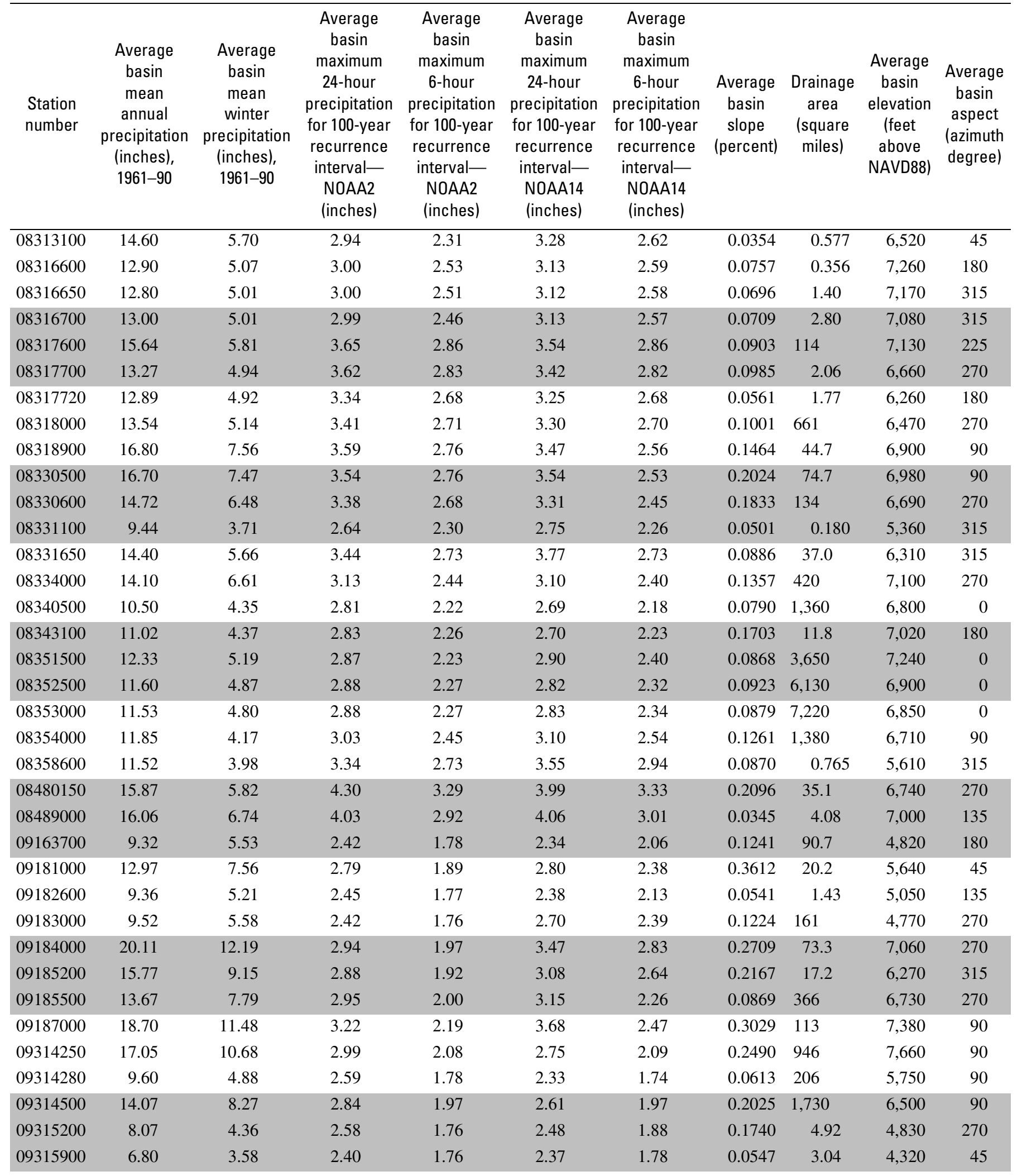


Appendix 2. Basin and climatic characteristics determined using Geographical Information System Weasel (U.S. Geological Survey, 2000)-Continued.

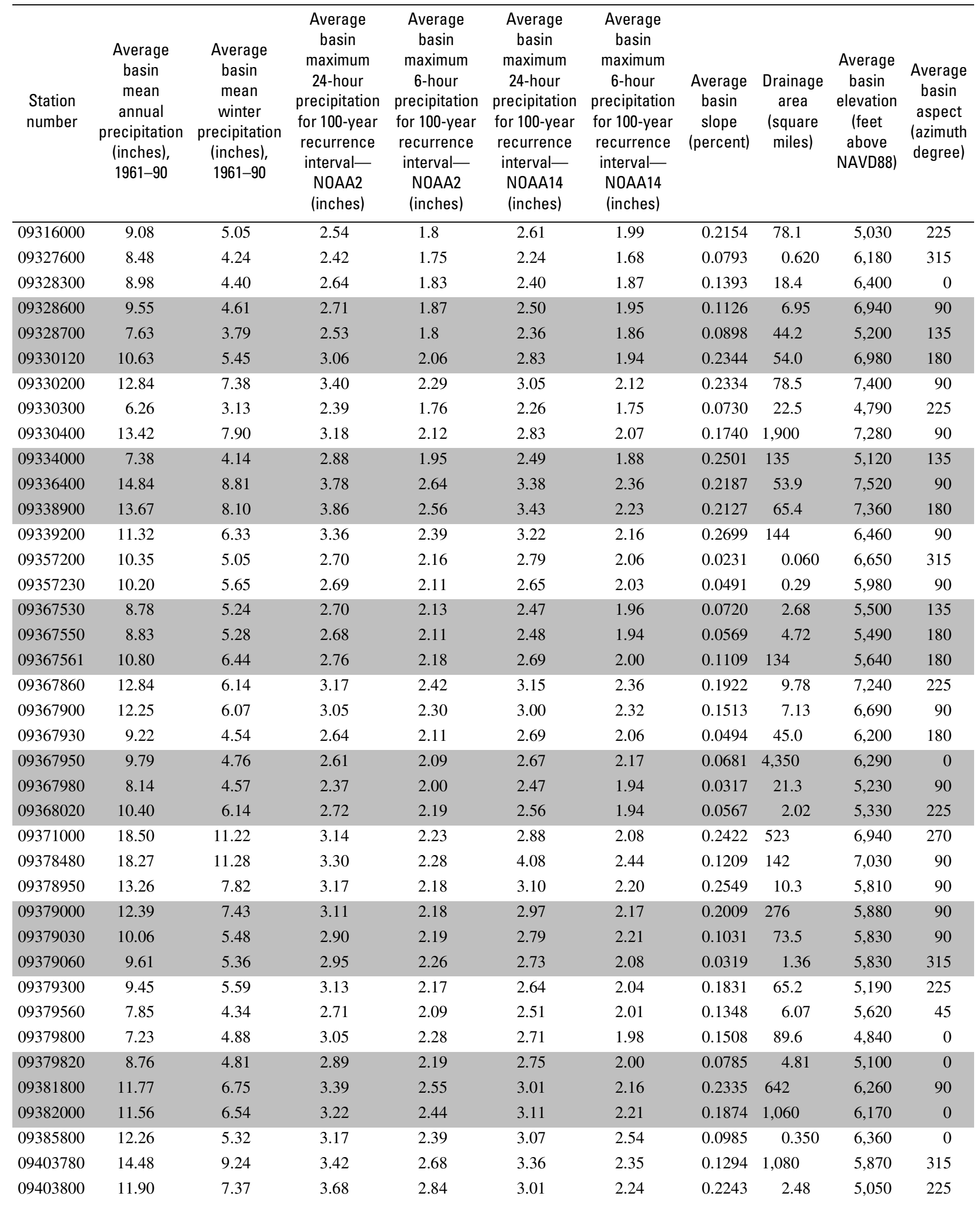


Appendix 2. Basin and climatic characteristics determined using Geographical Information System Weasel (U.S. Geological Survey, 2000)-Continued.

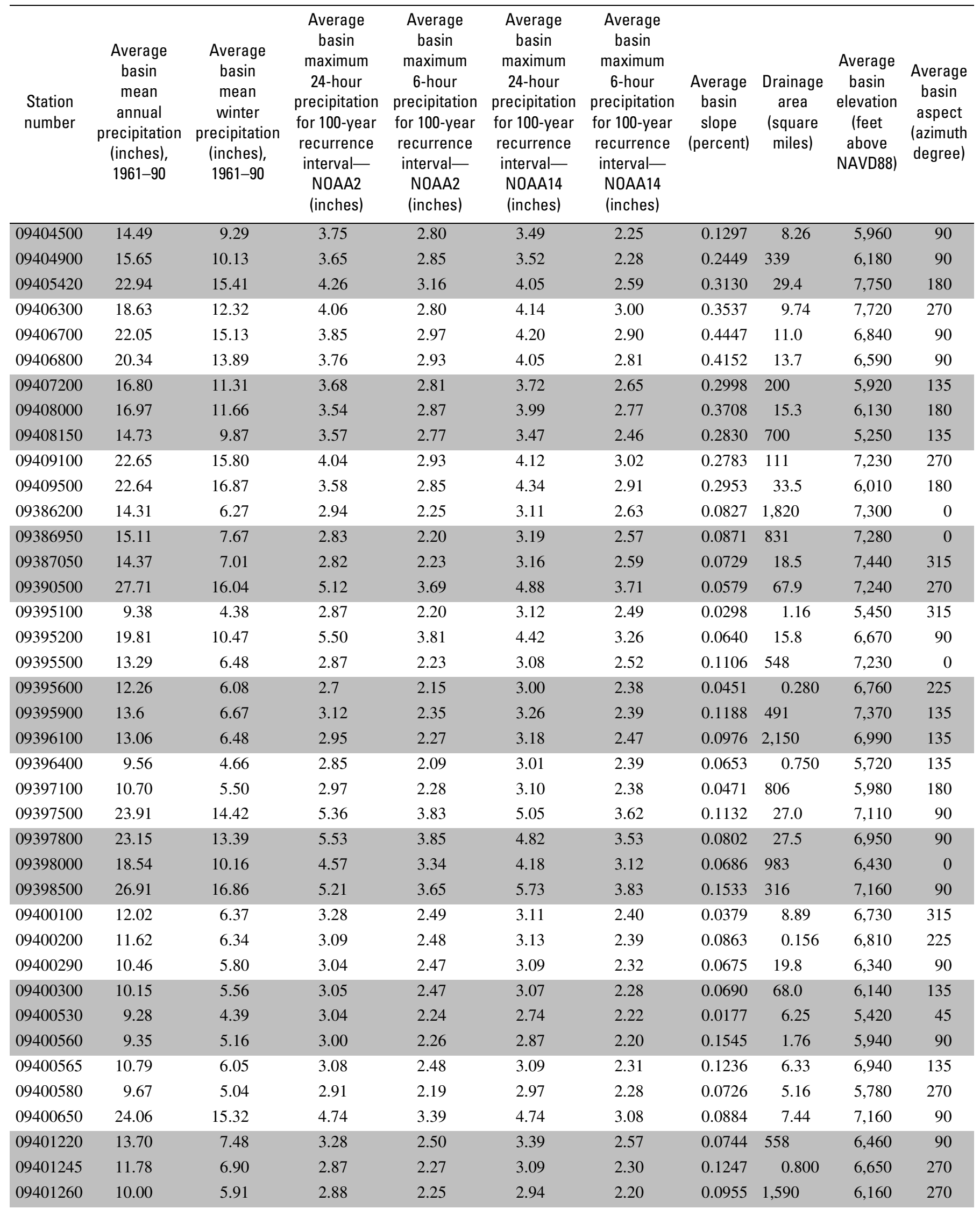


Appendix 2. Basin and climatic characteristics determined using Geographical Information System Weasel (U.S. Geological Survey, 2000)-Continued.

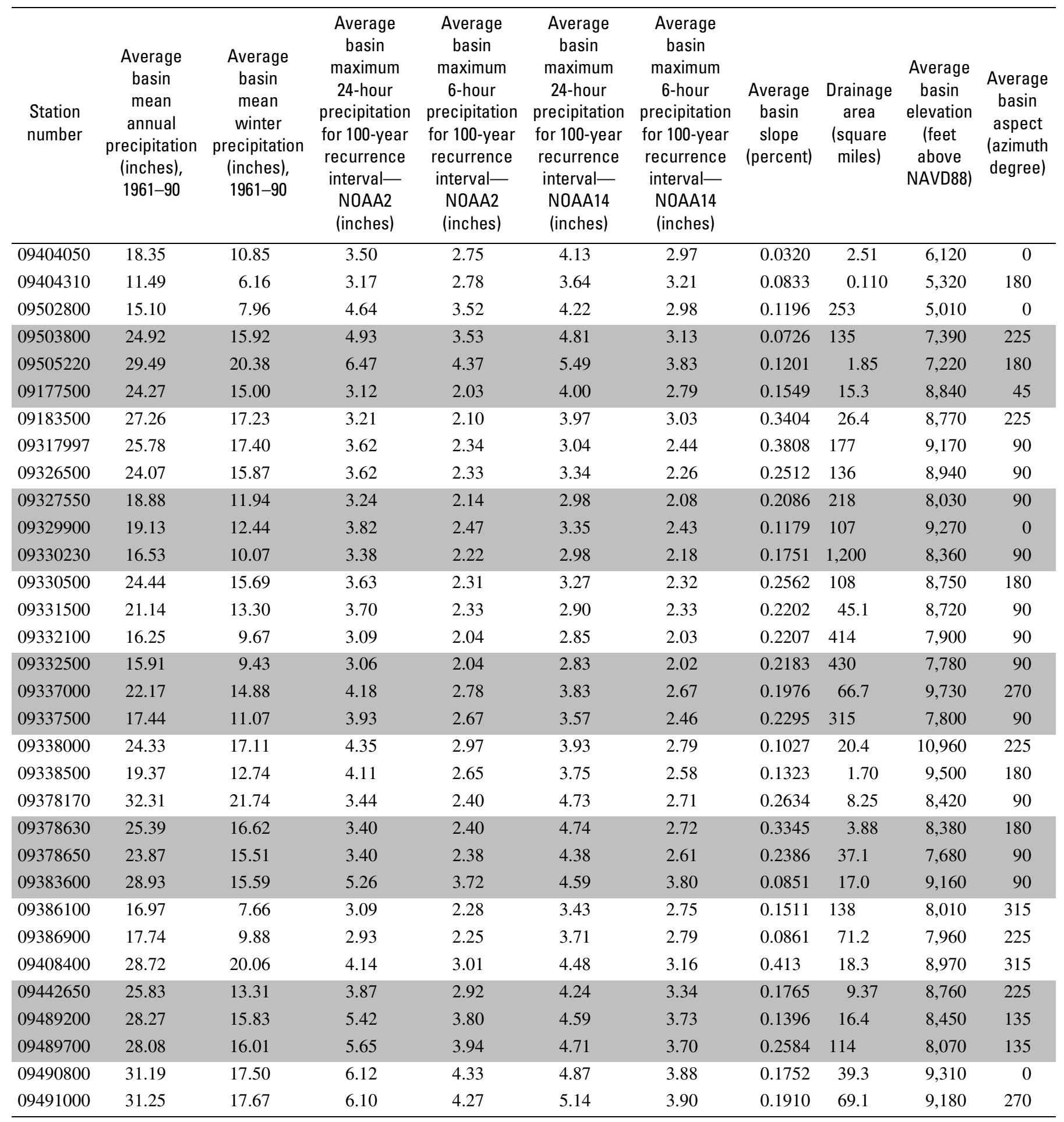

Prepared by the USGS New Mexico Water Science Center:

5338 Montgomery, NE, Suite 400

Albuquerque, New Mexico 87109

Information regarding water resources in New Mexico is available at http: //nm.water.usgs.gov/ 